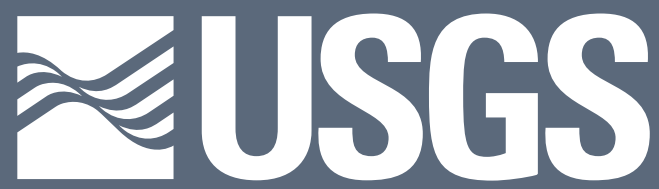

science for a changing world

\title{
Bathymetric Survey of the Nearshore from Belle Pass to Caminada Pass, Louisiana: Methods and Data Report
}

By Nancy T. DeWitt, James G. Flocks, Mark Hansen, Mark Kulp, and B.J. Reynolds

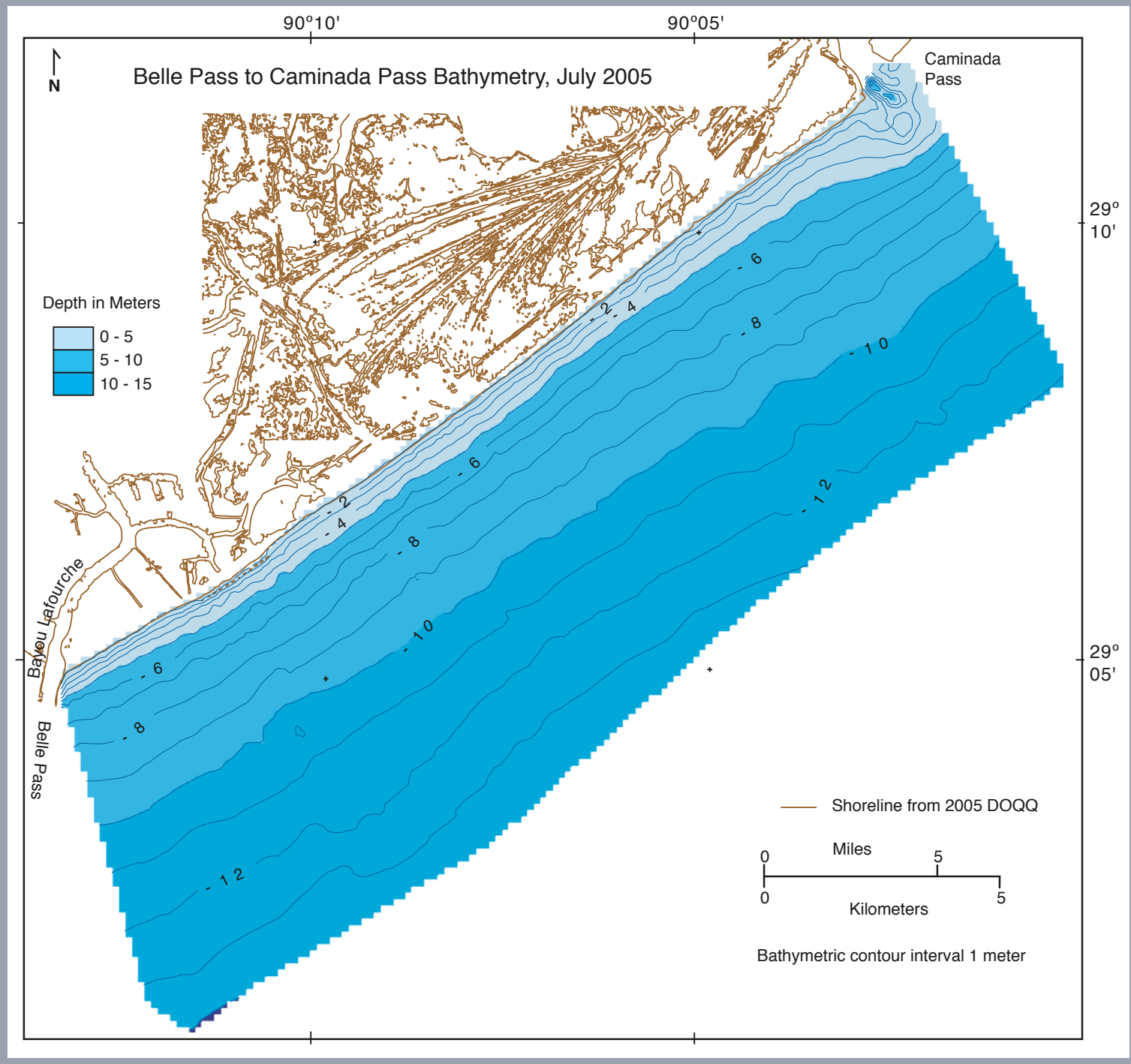

U.S. Geological Survey Data Series 312

U.S. Department of the Interior U.S. Geological Survey 


\section{Bathymetric Survey of the Nearshore from Belle Pass to Caminada Pass, Louisiana: Methods and Data Report}

By Nancy T. DeWitt, James G. Flocks, Mark Hansen, Mark Kulp, and B.J. Reynolds

U.S. Geological Survey Data Series 312

U.S. Department of the Interior

U.S. Geological Survey 


\title{
U.S. Department of the Interior DIRK KEMPTHORNE, Secretary
}

\section{U.S. Geological Survey Mark D. Myers, Director}

\author{
U.S. Geological Survey, Reston, Virginia 2007 \\ For product and ordering information: \\ World Wide Web: http://www.usgs.gov/pubprod \\ Telephone: 1-888-ASK-USGS
}

For more information on the USGS - the Federal source for science about the Earth, its natural and living resources, natural hazards, and the environment:

World Wide Web: http://www.usgs.gov

Telephone: 1-888-ASK-USGS

Suggested citation:

DeWitt, N.T., Flocks, J. G. Hansen, Mark, Kulp, Mark, Reynolds, B.J., 2007, Bathymetric survey of the nearshore from Belle Pass to Caminada Pass, Louisiana: Methods and data report: U.S. Geological Survey Data Series 312, one CD-ROM. Also available online at http://pubs.usgs.gov/

For copies of the CD contact:

Nancy T. DeWitt

Marine Geologist

U.S. Geological Survey

Florida Integrated Science Center--St. Petersburg

600 4th Street South

St. Petersburg, Florida 33701

(727) 803-8747 x3058

ndewitt@usgs.gov

http://coastal.er.usgs.gov/

Any use of trade, product, or firm names is for descriptive purposes only and does not imply endorsement by the U.S. Government.

Although this report is in the public domain, permission must be secured from the individual copyright owners to reproduce any copyrighted material contained within this report. 


\section{Contents}

Abstract

Introduction

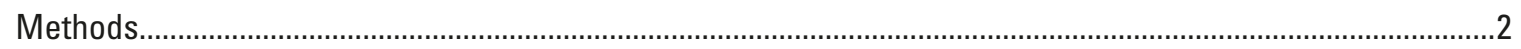

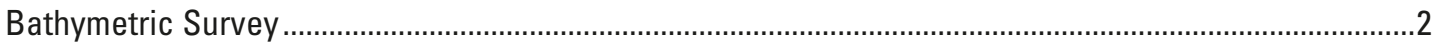

Survey Equipment.

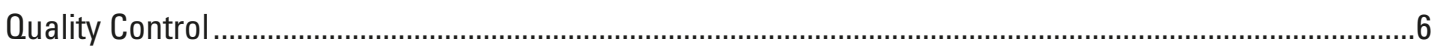

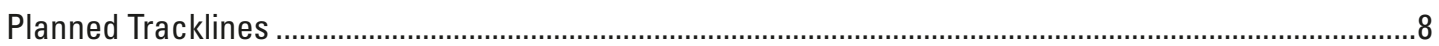

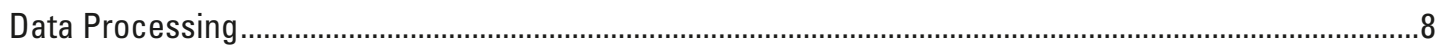

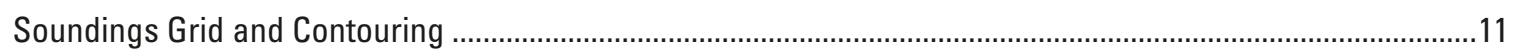

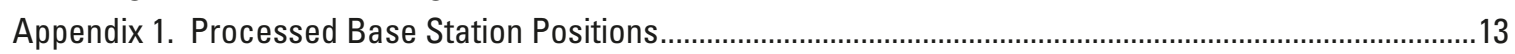

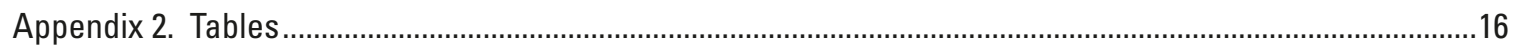

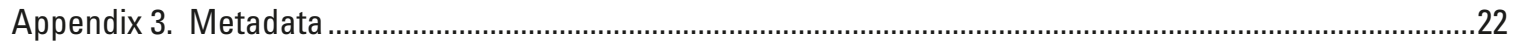




\section{Figures}

Figure 1. Map of the Louisiana coastline showing location of the Caminada-Moreau headland between

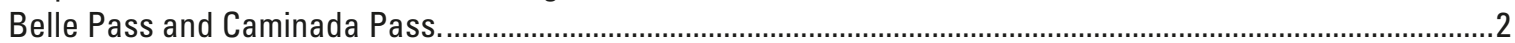

Figure 2. Comparison of the shoreline position at Belle Pass in the 1880s (left) and 1980s (right) .................................3

Figure 3. Seafloor change in meters in the area for two time periods, 1880 s to $1930 \mathrm{~s}$ (left) and 1930s to 1980s (right).....3

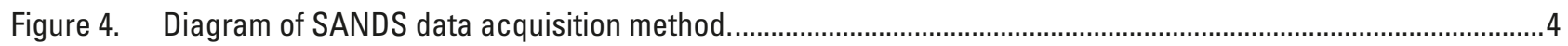

Figure 5. Diagram of SANDS data processing system. …….................................................................................

Figure 6. Photographs of the hardware components used on the survey vessel (rover) and at the benchmark (base

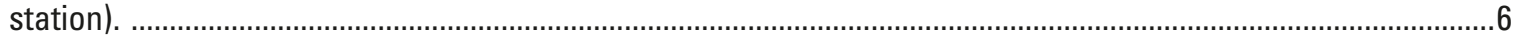

Figure 7. Photographs of the "bar check" system, from side view and top view.

Figure 8. Sounding tracklines (red lines) from this study, overlain on the survey acquired by the USGS in the 1980s, shows the close correlation between tracklines.

Figure 9. Diagram of the post processing workflow showing the various software components used to derive a bathymetric map and other data products

Figure 10. Bathymetric contours with color shading generated from the sounding tracklines (shown in fig. 8), Belle Pass to Caminada Pass

Figure A1. Map showing base station locations with a 10-kilometer radius extent for the roving boat. 13

Figure A2. Photographs showing BLUM base station setup and benchmark stamping. 14

Figure A3. Photographs showing N221 base station setup and benchmark stamping. 15

\section{Tables}

Table A1. General Base Information

Table A2. Automated GPS Inferred Positioning System (GIPSY) Results.......................................................................17

Table A3. On Line Positioning User Service (OPUS) Results ...............................................................................................18

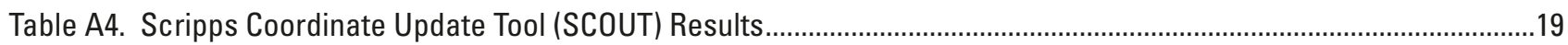

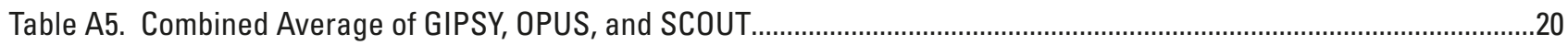

Table A6. Final Numbers Compared to Published Numbers .......................................................................................................21 


\section{Acronyms and Abbreviations}

\begin{tabular}{|c|c|}
\hline Acronym or Abbreviation & Meaning \\
\hline CORS & Continuously Operating Reference Stations \\
\hline $\mathrm{cm}$ & centimeters \\
\hline DGPS & Differential GPS \\
\hline DOQQ & Digital Ortho Quarter Quad \\
\hline ESRI & Environmental Systems Research Institute \\
\hline FGDC & Federal Geographic Data Committee \\
\hline $\mathrm{ft}$ & foot \\
\hline GEOID03 & Geoid Model 2003 \\
\hline GIPSY & GPS-Inferred Positioning System \\
\hline GPS & Global Positioning System \\
\hline IGS & International GPS Service Station \\
\hline Inc & Incorporated \\
\hline $\mathrm{kHz}$ & kilohertz \\
\hline $\mathrm{km}$ & kilometer \\
\hline $\mathrm{km}^{2}$ & square kilometer \\
\hline LDNR & Louisiana Department of Natural Resources \\
\hline $\mathrm{m}$ & meter \\
\hline $\mathrm{ms}$ & millisecond \\
\hline $\mathrm{m} / \mathrm{s}$ & meters per second \\
\hline NAD 83 & North American Datum 1983 \\
\hline NAVD 88 & North American Vertical Datum 1988 \\
\hline NAVSTAR & Navigation Signal Timing and Ranging \\
\hline NGS & National Geodetic Survey \\
\hline NOAA & National Oceanic and Atmospheric Administration \\
\hline NOS & National Ocean Service \\
\hline OPUS & On Line Positioning User Service \\
\hline PDOP & percent dilution of position \\
\hline PID & permanent identifiers \\
\hline RMS & root mean square \\
\hline $\mathrm{R} / \mathrm{V}$ & research vessel \\
\hline $\mathrm{s}$ & second \\
\hline SANDS & System for Accurate Nearshore Depth Surveying \\
\hline SCOUT & Scripps Coordinate Update Tool \\
\hline UNO & University of New Orleans \\
\hline USGS & United States Geological Survey \\
\hline UTM & Universal Transverse Mercator \\
\hline WGS84 & World Geodetic System 1984 \\
\hline ybp & years before present \\
\hline
\end{tabular}




\section{Conversion Factors}

\section{SI to Inch/Pound}

\begin{tabular}{|c|c|c|}
\hline Multiply & By & To obtain \\
\hline \multicolumn{3}{|c|}{ Length } \\
\hline centimeter $(\mathrm{cm})$ & 0.3937 & inch (in.) \\
\hline millimeter (mm) & 0.03937 & inch (in.) \\
\hline meter $(\mathrm{m})$ & 3.281 & foot $(\mathrm{ft})$ \\
\hline kilometer $(\mathrm{km})$ & 0.6214 & mile (mi) \\
\hline kilometer $(\mathrm{km})$ & 0.5400 & mile, nautical (nmi) \\
\hline meter $(\mathrm{m})$ & 1.094 & yard $(y d)$ \\
\hline \multicolumn{3}{|c|}{ Area } \\
\hline square meter $\left(\mathrm{m}^{2}\right)$ & 0.0002471 & acre \\
\hline square centimeter $\left(\mathrm{cm}^{2}\right)$ & 0.001076 & square foot $\left(\mathrm{ft}^{2}\right)$ \\
\hline square meter $\left(\mathrm{m}^{2}\right)$ & 10.76 & square foot $\left(\mathrm{ft}^{2}\right)$ \\
\hline square kilometer $\left(\mathrm{km}^{2}\right)$ & 0.3861 & square mile $\left(\mathrm{mi}^{2}\right)$ \\
\hline
\end{tabular}




\title{
Bathymetric Survey of the Nearshore from Belle Pass to Caminada Pass, Louisiana: Methods and Data Report
}

\author{
By Nancy T. DeWitt' ${ }^{1}$, James G. Flocks' ${ }^{1}$, Mark Hansen'1, Mark Kulp², and B.J. Reynolds'
}

\section{Abstract}

The U.S. Geological Survey (USGS), in cooperation with the University of New Orleans (UNO) and the Louisiana Department of Natural Resources (LDNR), conducted a high-resolution, single-beam bathymetric survey along the Louisiana southern coastal zone from Belle Pass to Caminada Pass. The survey consisted of 483 line kilometers of data acquired in July and August of 2005. This report outlines the methodology and provides the data from the survey. Analysis of the data and comparison to a similar bathymetric survey completed in 1989 show significant loss of seafloor and shoreline retreat, which is consistent with previously published estimates of shoreline change in the study area.

\section{Introduction}

The barrier island and deltaic headland shorelines of the Mississippi Delta plain are rapidly retreating (Kulp and others, 2004). High rates of delta plain subsidence, ongoing eustatic sea-level rise, and other processes such as storm impacts contribute to shoreline loss (Penland and Ramsey, 1990; Dokka and Shinkle, 2003). These and other factors contribute to as much as 14 meters of shoreline retreat per year, resulting in more than 60 square kilometers of

\footnotetext{
${ }^{1}$ USGS Florida Integrated Science Center, 600 4th Street South, St. Petersburg, FL 33701.

${ }^{2}$ University of New Orleans, Department of Earth and Environmental Sciences, 2000 Lakefront, New Orleans, LA, 70148.
}

annual land loss. Located southwest of New Orleans, the Caminada-Moreau headland (fig. 1) is a depositional vestige of the Lafourche Delta complex that prograded the area between 3,500 years before present and 1,500 years before present (Frazier, 1967; Törnqvist and others, 1996). Delta development diminished through time with increasing river diversion eastward to the Plaquemines-Modern Delta complex. For a detailed summary of the geologic framework of the Caminada-Moreau headland, see Kulp and others (2003). Today, sediment deposition is largely nonexistent because Bayou Lafourche, the remnant distributary of the delta complex, was dammed in 1904 (Mossa and others, 1985). Within the last century the increasing dominance of marine processes over fluvial deposition has led to a relative sea-level rise, driving a transgressive reworking of the headland. As a result, the shoreline is in retreat from advancing wave action. The Caminada-Moreau headland serves a vital role to southern Louisiana and the Nation as it protects a petroleum-industry infrastructure that supports almost half of the oil production from the deep Gulf of Mexico, and 17 percent of the oil and gas consumed in the United States (Greater Lafourche Port Commission, 2006). This important shoreline has some of the highest erosion rates within the delta plain (Williams and others, 1992) and is intensively monitored. In a widely referenced U.S. Geological Survey atlas on seafloor change, 


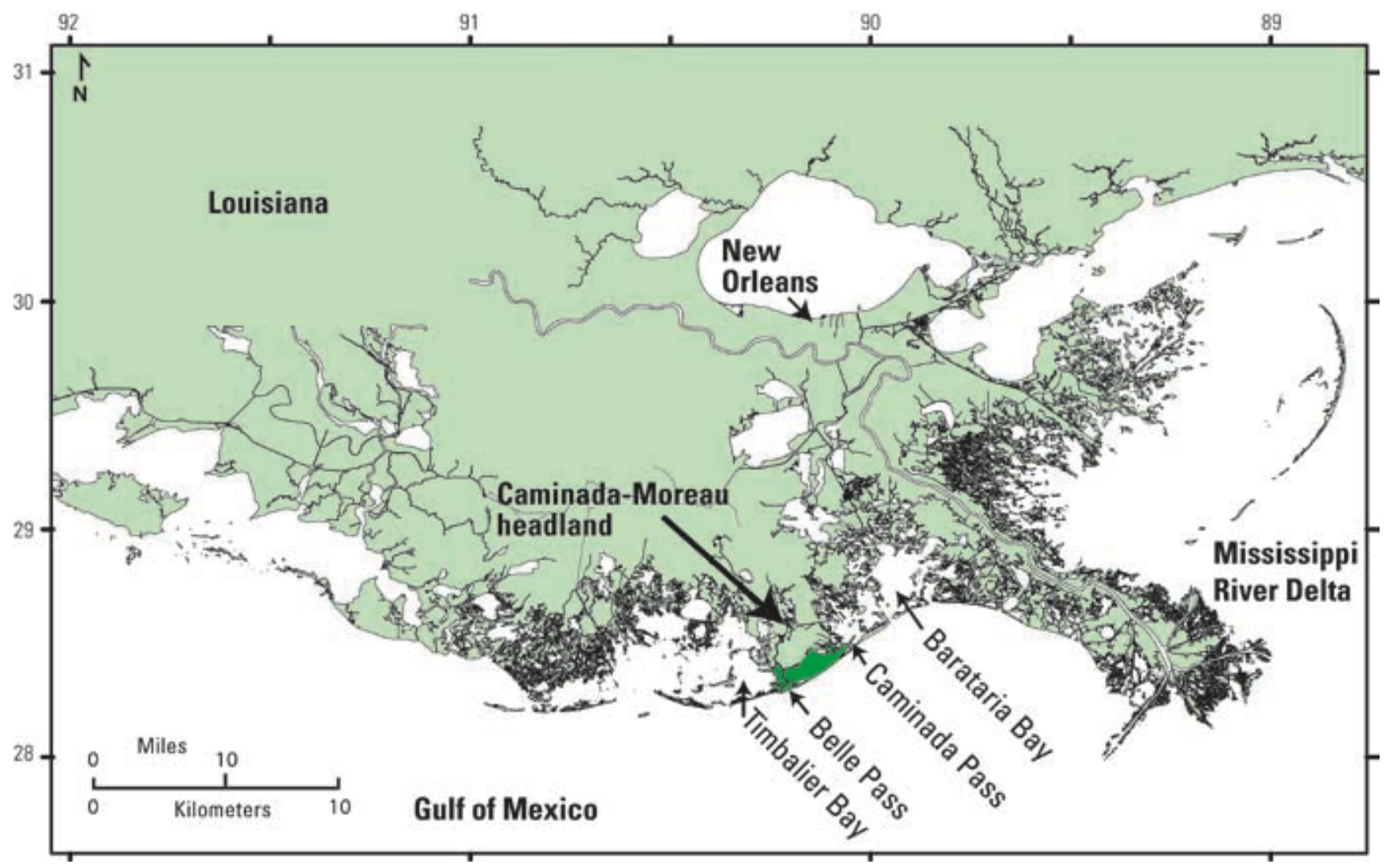

Figure 1. Map of the Louisiana coastline showing location of the Caminada-Moreau headland between Belle Pass and Caminada Pass.

List and others (1994) conducted seafloor change analysis for three time periods (1880s, 1930s, and 1980s). Through comparison of historical charts and aerial photographs, they showed that as much as $3 \mathrm{~km}$ of landward translation of the coast has taken place during the past 100 years (fig. 2). This erosion applies not only to the shoreface but to water depths below average wavebase (fig. 3).

In July and August of 2005, the USGS, in collaboration with the University of New Orleans (UNO) and the Louisiana Department of Natural Resources (LDNR), conducted high-resolution bathymetric surveys along the $20-\mathrm{km}$ stretch of coast between Belle Pass and Caminada Pass (fig. 1) as part of a coastal erosion study. Bathymetric coverage extended from the shoreline to $7 \mathrm{~km}$ offshore. The goal of the bathymetric survey was to provide baseline data that could be used to quantify past and future shoreline and seafloor change and provide a database for assessing future storm impacts.

\section{Methods}

\section{Bathymetric Survey}

The seafloor-elevation survey was conducted using the System for Accurate Nearshore Depth Surveying (SANDS). As a result of Hurricane Andrew in 1992, SANDS was developed and tested by the USGS Center for Coastal and Watershed Studies in St. Petersburg, FL. SANDS, a single-beam acoustic (sounding) Global Positioning System (GPS)-based hydrographic 

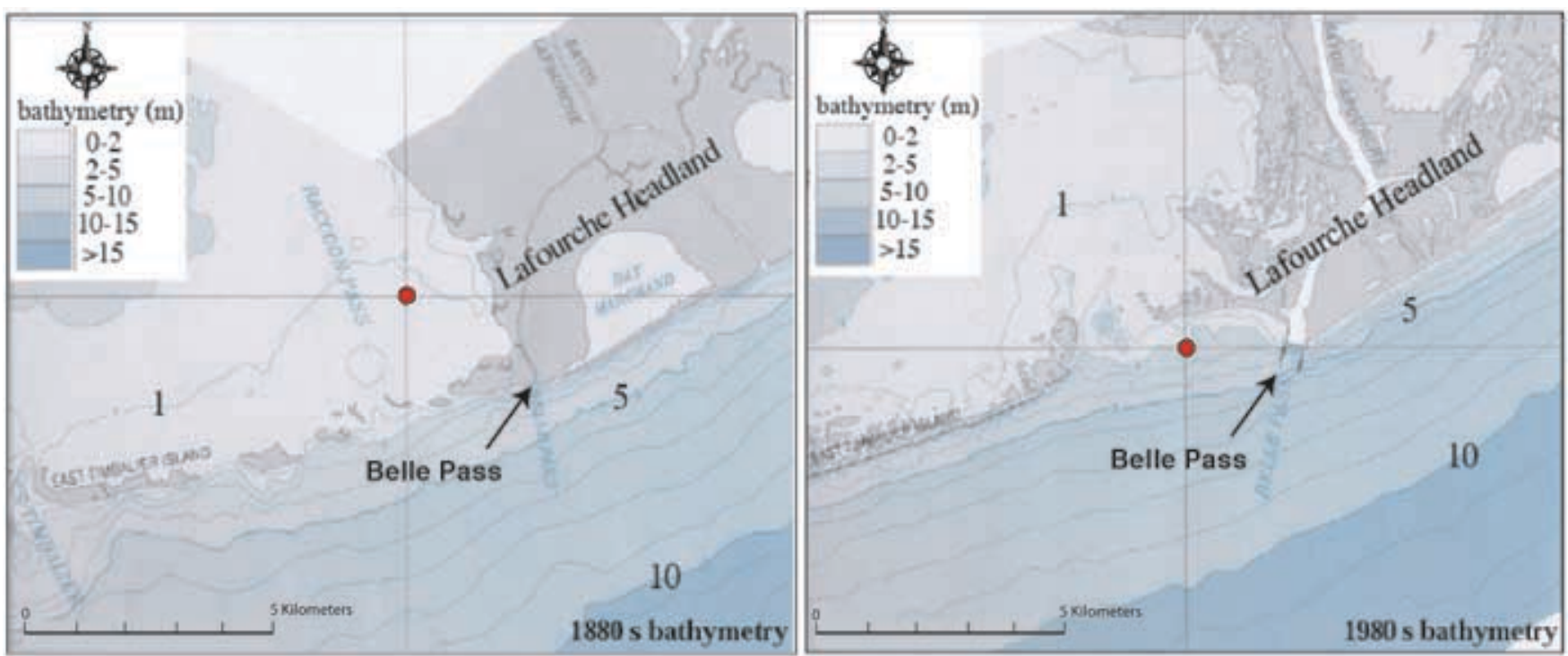

Figure 2. Comparison of the shoreline position at Belle Pass in the 1880s (left) and 1980s (right) (from List and others, 1994; modified from Kulp and others, 2004). Red circle shows same geographic position in both frames and reflects 3 kilometers of shoreline retreat. Lafourche headland corresponds to Caminada-Moreau headland.
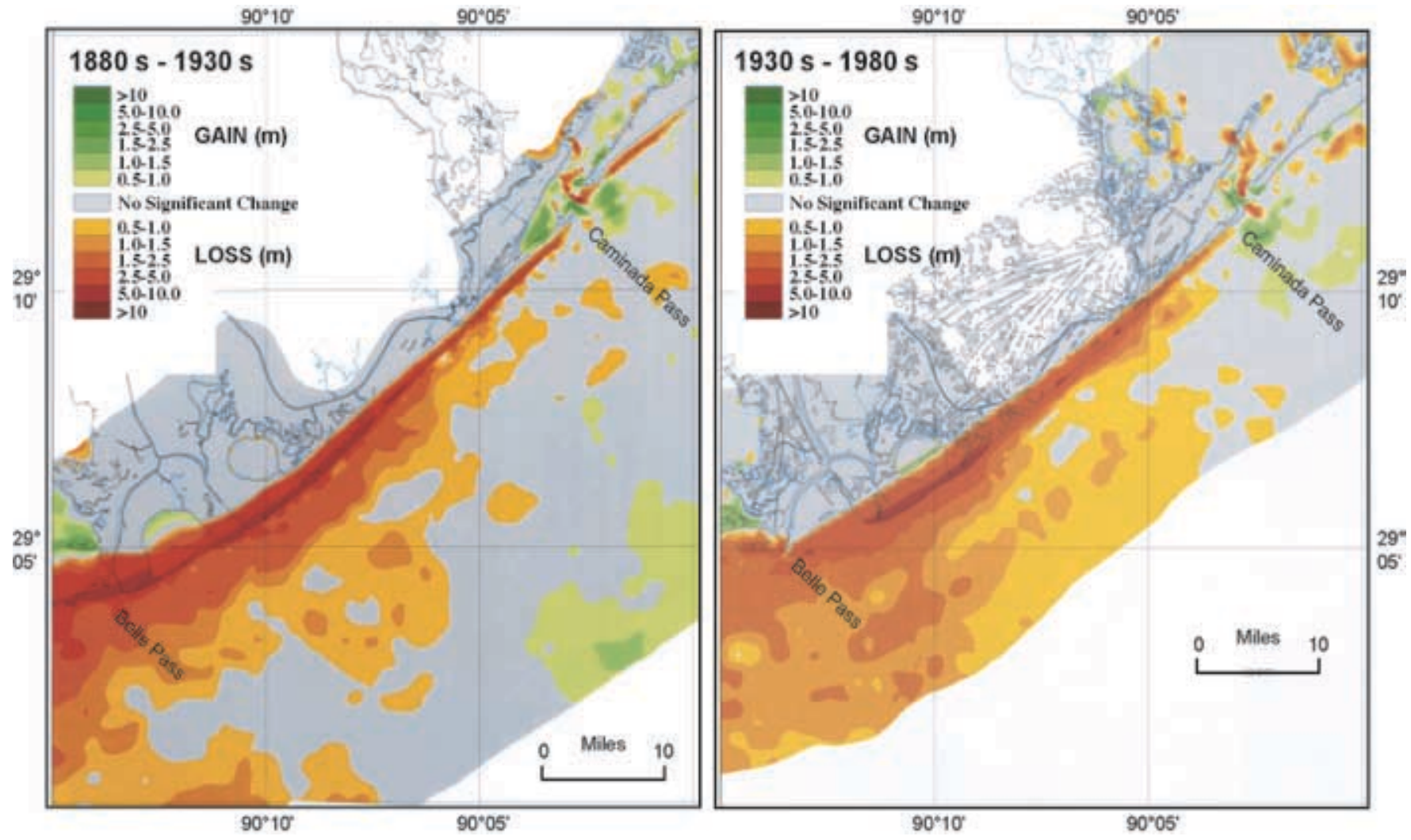

Figure 3. Seafloor change in meters in the area for two time periods, 1880s to 1930s (left) and 1930s to 1980s (right). Green shows accretion and red shows erosion for the two 50-year periods. Modified from List and others (1994). 
system, has two components, data acquisition and data processing (fig. 4 and fig. 5).

Differential boat position was recorded using GPS referenced to a land-based benchmark. To increase positional accuracy, GPS base stations are positioned over geographic benchmarks located within $10 \mathrm{~km}$ of the survey area. These stations record position relative to GPS satellites throughout the survey. Boat position, motion (heave, pitch, and roll), and depth readings collected during the survey are stored on an onboard laptop computer. These boat components are merged into a single dataset using time correlations. The system is described in detail in the following section.

\section{Survey Equipment}

The acquisition hardware is composed of four separate units: a GPS system on land (base station), a GPS system on the survey vessel (rover), a motion sensor (vessel heave, pitch, and roll), and an echosounder. The hardware units on the vessel are mounted in line on a rigid pole with the echosounder transducers just below the waterline. The motion sensor is housed in

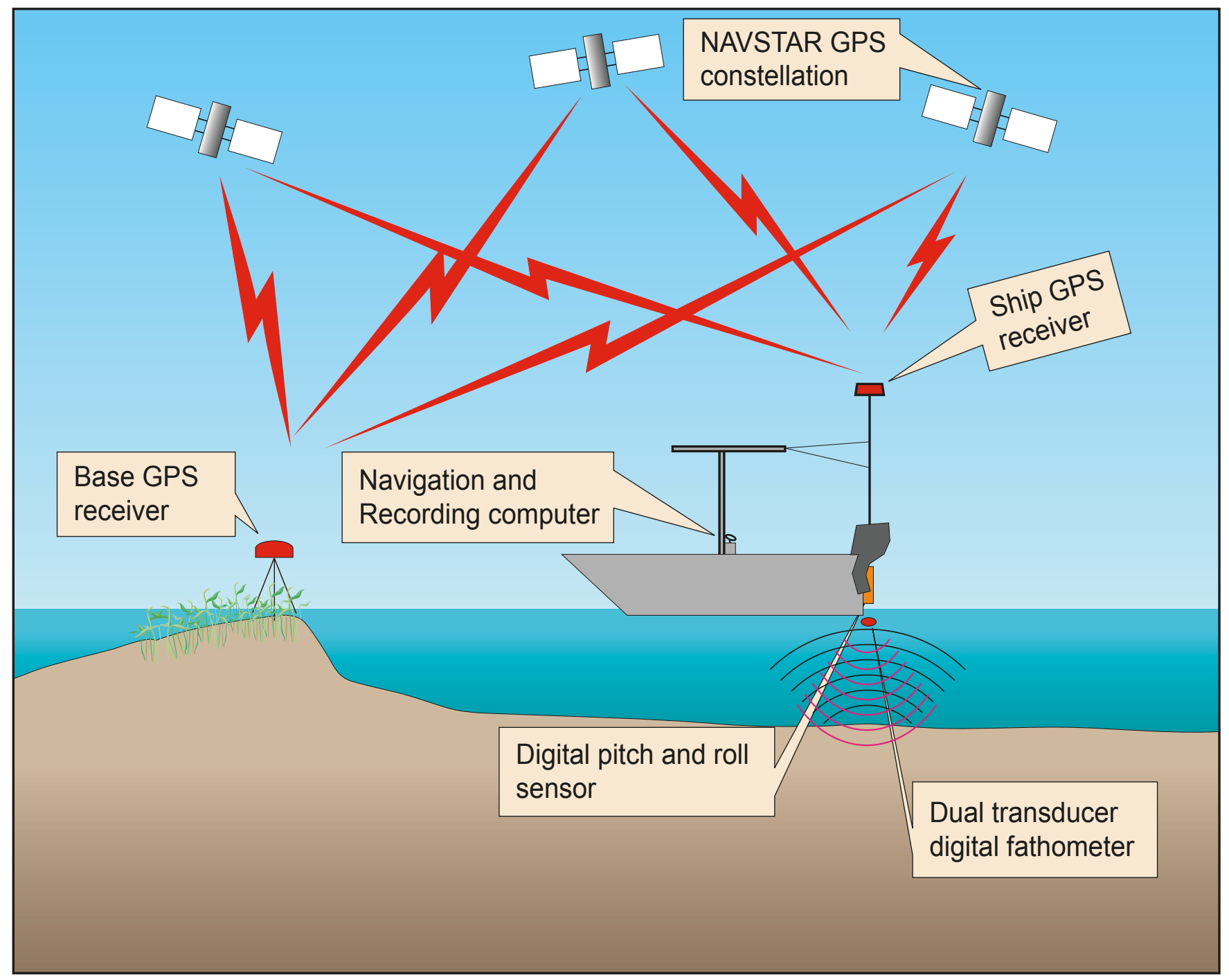

Figure 4. Diagram of SANDS data acquisition method. 


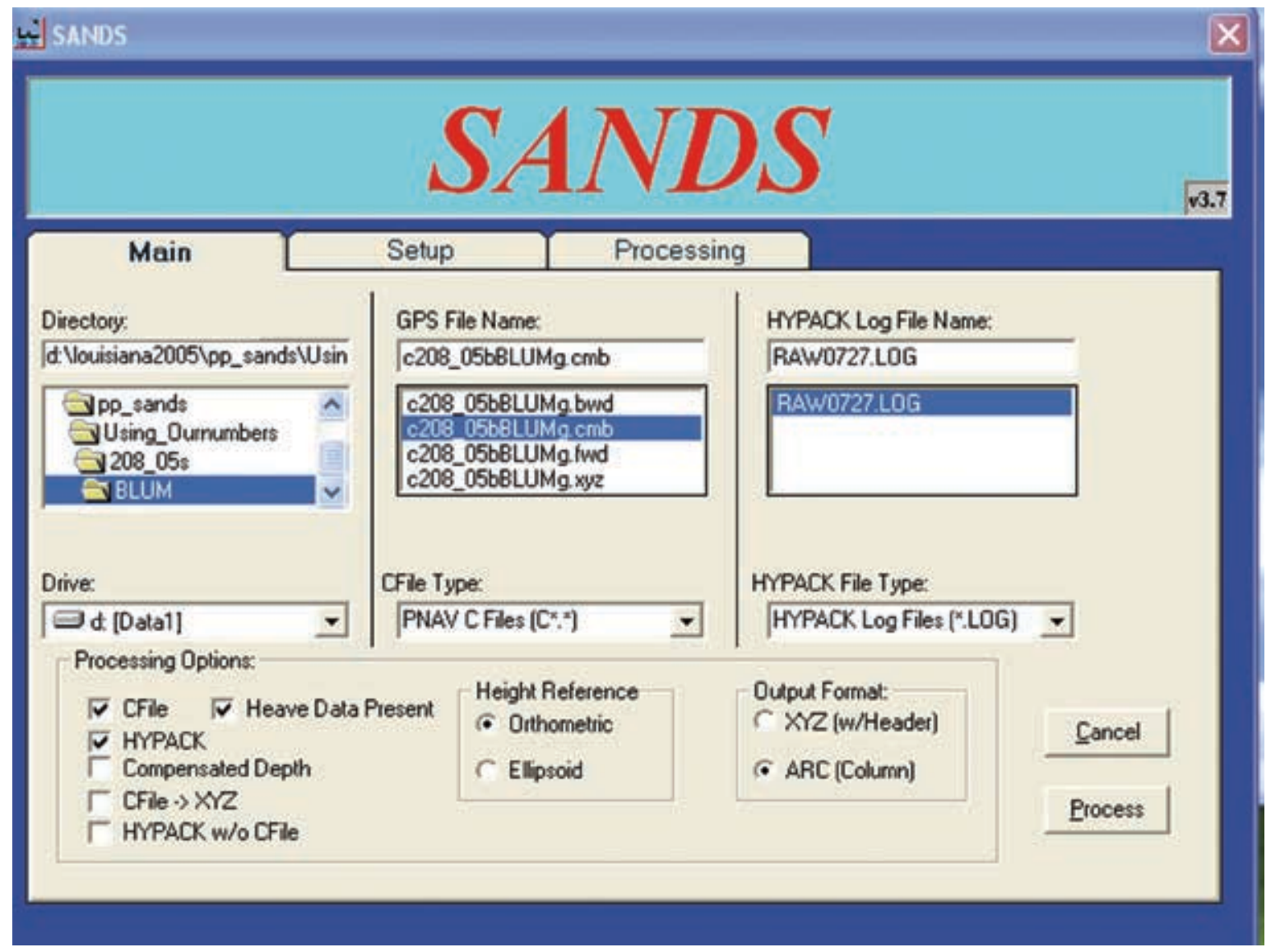

Figure 5. Diagram of SANDS data processing system.

a watertight steel container mounted above the transducers, and the GPS choke ring antenna is mounted at the top of the pole $3 \mathrm{~m}$ above the transducers (fig. 6).

The antennas receive the positioning signal from the Navigation Signal Timing and Ranging (NAVSTAR) GPS satellite constellation (fig. 4). Two Ashtech Z-Xtreme GPS receivers with internal data card storage simultaneously record 12-channel full-carrier-phase positioning signals (L1/L2) from the satellites. The base receiver and the rover receiver record their positions concurrently at 1-second (s) recording intervals throughout the survey period. Boat motion (heave, pitch, and roll) is recorded at 50-milliseconds (ms) intervals using a TSS DMS-05 sensor. Boat pitch and roll measurements from the sensor are utilized by SANDS in post processing of the data. Heave motion is a major depth error component. Although motion sensors can reasonably compensate for vessel motion, they are still subject to constant drifts and require visual monitoring (via readout) during survey and in post processing. In SANDS, the heave motion from the TSS is not used but is more accurately represented by using the GPS component.

Depth soundings are recorded at 50-ms intervals using a Marimatech E-SEA-103 echosounder system with dual 208 kilohertz $(\mathrm{kHz})$ transducers. Designed for shallow-water work, one transducer generates a sound pulse while the other one receives the bottom returned signal. The transducer generates a narrow 4-degree "beam" 


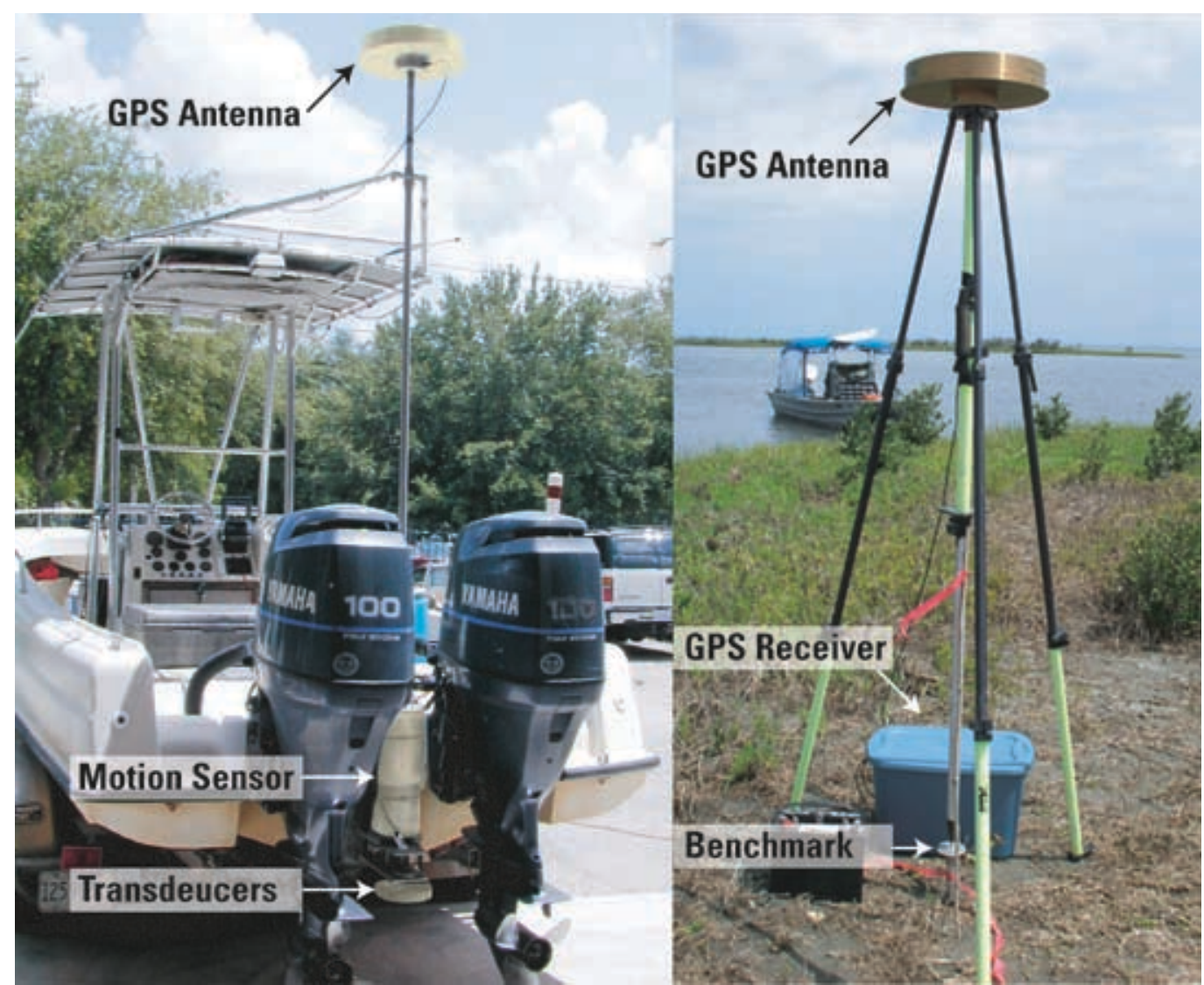

Figure 6. Photographs of the hardware components used on the survey vessel (rover) and at the benchmark (base station).

sound pulse that produces a small sonar footprint for higher resolution and accuracy.

The data from the GPS receiver, motion sensor, and fathometer are streamed in real time to a laptop computer running the Windows operating system. The acquisition software used is HYPACK MAX version 4.3A (HYPACK, Inc.), a marine surveying, positioning, and navigation software package. The acquisition software combines the data streams from the various components into a single raw data file, with each device string referenced by a device identification code and timestamped to the nearest millisecond. The software also manages the planned-transect information, providing real-time navigation, steering, correction, data quality, and instrumentation-status information to the boat operator.

A 22 foot (ft) Boston Whaler $(R / V$ Streeterville) with outboard motors was fitted with the acquisition hardware and software (fig. 6). The vessel is capable of operating in 46 centimeters $(\mathrm{cm})$ of water and provides a stable platform for daylight, nearshore operations.

\section{Quality Control}

Vertical and horizontal positioning and resolution.-- SANDS can function in water depths between $0.25 \mathrm{~m}$ and $100 \mathrm{~m}$ and can resolve bottom features ranging from $0.02 \mathrm{~m}$ to $0.03 \mathrm{~m}$ in height. The E-SEA-103 fathometer uses a filtering algorithm that compares successive bottom echoes to maintain an accurate track of the seafloor, 
reducing interference from artifacts in the water column. Depth measurements from SANDS are relative to an Earth-centered ellipsoid, eliminating errors associated with water surface elevation or tidally based bathymetric systems. The final water depth values are in elevations relative to the North American Vertical Datum of 1988 (NAVD 88 ), to provide elevations relative to a known datum.

Planned crossing lines are surveyed as a quality control measure and serve as a check in the post processing steps of SANDS. Similar (within $10 \mathrm{~cm}$ ) positional measurements where survey lines cross are useful indications of measurement accuracy (assuming no change in seafloor depth), since lines surveyed at different times of the day are supported by GPS information from different satellites within the NAVSTAR constellation. In theory, the values at a crossing point should be the same; any deviation helps isolate incorrect values along individual tracklines. Several external factors including GPS cycle-slips, weather, and extreme surface conditions can contribute to incorrect values. For the study area, the SANDS crossing line measurements ranged from $0.02 \mathrm{~m}$ to $0.10 \mathrm{~m}$ vertically.

All horizontal positioning is referenced to Universal Transverse Mercator (UTM) Zone 15, North American Datum of 1983 (NAD 83), and tied to the Louisiana Coastal Zone GPS network using benchmarks approved by the LDNR. The horizontal accuracy of the post processed GPS signal from these benchmarks ranges from $0.01 \mathrm{~m}$ to $0.03 \mathrm{~m}$. SANDS uses the National Oceanic and Atmospheric Administration / National Geodetic Survey (NOAA/NGS) GEOID03 software to reference the data to NAD 83.
Sound velocity.-- In shallow water surveys, the high sound velocity to depth ratio and the assumed mixing of the water tend to decrease the significance of sound velocity variations due to salinity and temperature gradients in the water column. For these reasons, the use of an average sound velocity is suitable within the depth range of surveying. A fixed "bar check" is an accepted method used to correct for sound velocity variations and index errors in the fathometer. An aluminum pipe with a top plate is suspended 1.0 $\mathrm{m}$ below the transducer (fig. 7). This known distance is compared to the distance determined by the sounding system, using an assumed average sound velocity of 1,500 meters per second $(\mathrm{m} / \mathrm{s})$. This check is conducted on a daily basis, and any deviation between the depth of the reference bar and the measured depths is used to correct subsequent recorded soundings for that day during post processing. In shallow water operations, depth deviations are usually minimal in proportion to sound velocity and the short distance of signal travel.

GPS.-- The GPS antennas receive positional information from the NAVSTAR satellite constellation, which includes the Percent Dilution of Position (PDOP). PDOP is a measurement of the relative signal strength of the GPS satellite configuration as measured internally by the GPS system and displayed as a value typically between 1 and 4. The PDOP is a proxy for position error; the lower the value, the higher the accuracy. When PDOP readings exceed a value of 3 , operations are halted, or data were removed from the dataset during post processing.

LDNR GPS network.-- The LDNR has established a series of benchmarks along the 


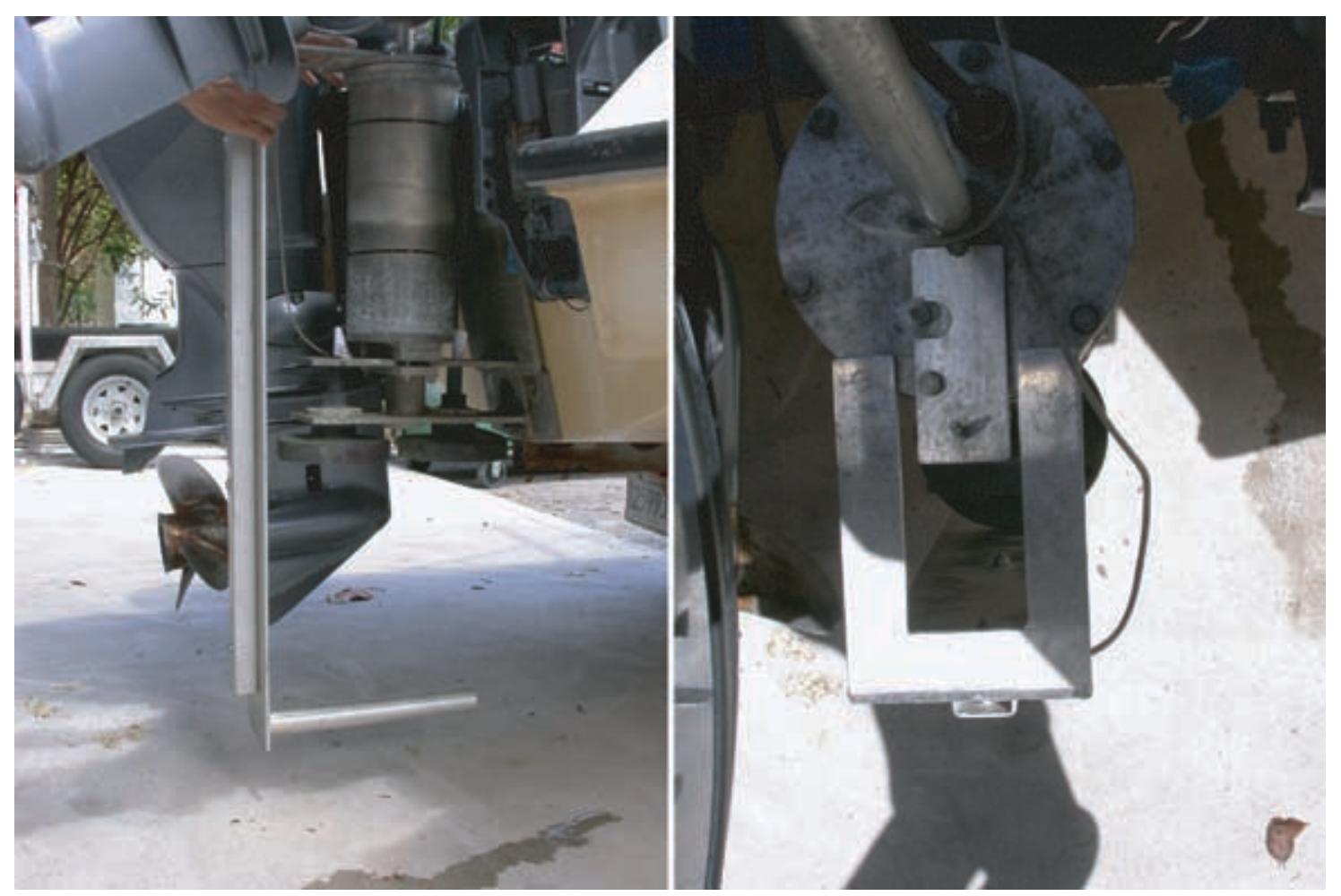

Figure 7. Photographs of the "bar check" system, from side view and top view.

Louisiana coastal zones that are surveyed using a specific protocol. For information on this network, see Louisiana Department of Natural Resources (2003). The published orthometric heights from these benchmarks, along with derived heights measured by the base station during the survey, are used in the post processing of the positioning data. The survey area was constrained to within a $10-\mathrm{km}$ radius of a benchmark to minimize errors in GPS measurements. Base station positions, and information used in this survey, can be found in appendix 1 .

\section{Planned Tracklines}

To optimize the assessment of seafloor change over time, the survey grid was designed to reoccupy the 1980s transect lines published in the List and others (1994) atlas (fig. 8). The survey grid consisted of 48 lines perpendicular to shore and shore-parallel lines for cross-checking purposes. The shore-perpendicular lines are spaced $0.5 \mathrm{~km}$ apart and alternate from $3.5 \mathrm{~km}$ to $8 \mathrm{~km}$ long. The shore-parallel lines trend along the modern shoreline, $2.5 \mathrm{~km}$ and $5 \mathrm{~km}$ offshore, and transect the 22-km survey area from Belle Pass to Caminada Pass. The shoreline transect was acquired as close to shore as conditions would allow, generally around $1 \mathrm{~m}$ in water depth. Additional seafloor measurements were acquired as appropriate within Belle Pass, Bayou Lafourche, and Caminada Pass to further constrain the relief. Approximately $480 \mathrm{~km}$ of data were collected throughout the survey.

\section{Data Processing}

A generalized workflow diagram of post processing is shown in figure 9. The diagram outlines the sequence of the various inputs and 


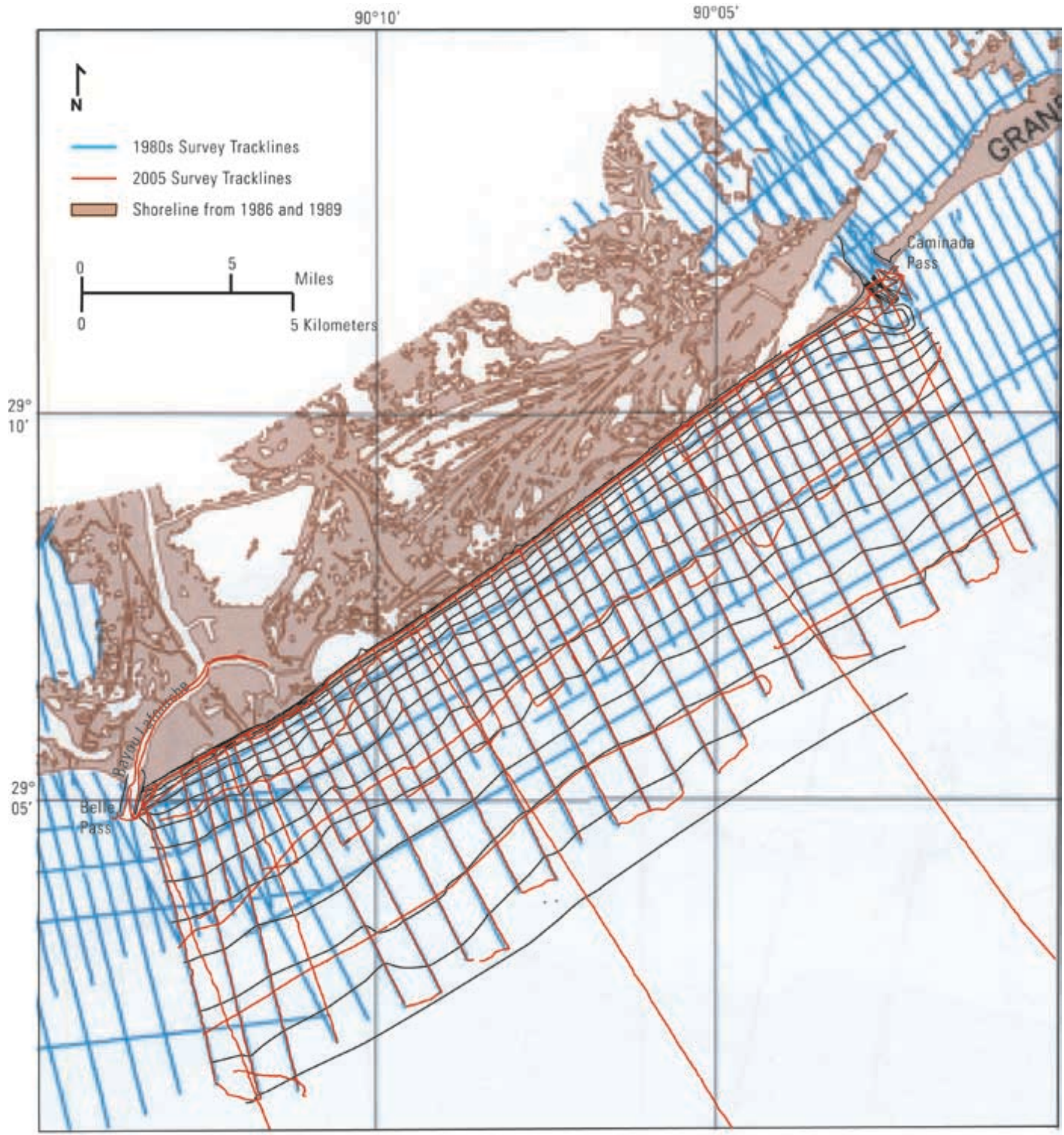

Figure 8. Sounding tracklines (red lines) from this study, overlain on the survey acquired by the USGS in the 1980s (from List and others, 1994), shows the close correlation between tracklines. Three lines extend to 13 kilometers offshore and reoccupy the profile lines $\mathrm{L}-\mathrm{N}$ from the List and others (1994) atlas. The shoreline is interpreted from aerial photography acquired in the 1980s. The 2005 survey (red lines) extends more than 200 meters inland of this previous shoreline because of the shoreline retreat that has taken place within the past 20 years. 
processing components that result in finished map products and data archive. The software components are described in the following section.

Base Station Data Processing: GIPSY, OPUS, and SCOUT static processing software.-- Three independent GPS autonomous processing software services are used to establish position, especially if a new benchmark is being used. Through an online submittal service, these automated programs process the long-duration time-series GPS data recorded by the base station receiver and return a corrected position relative to constellation conditions on the day of data acquisition.

Automated GPS-Inferred Positioning System (GIPSY), a service provided by NASA's Jet Propulsion Laboratory, is applied when the base location cannot be tied to an established network such as that of the NGS. Automated GIPSY software computes base station coordinates by accurately modeling the orbital trajectories of the NAVSTAR GPS satellites and provides a base coordinate that can be converted to the NAD 83 and the NAVD 88 datums. Horizontal resolution of the GIPSY output can be less than $1 \mathrm{~cm}$ root mean square (RMS).

NOAA and NGS provide the On-Line Positioning User Service (OPUS), which uses three Continuously Operating Reference Stations (CORS) reference sites to average three distinct single-baseline solutions computed by doubledifferenced, carrier phase measurements. The locations of the three most suitable CORS stations are based upon a series of tests that OPUS performs to select suitable stations for use in

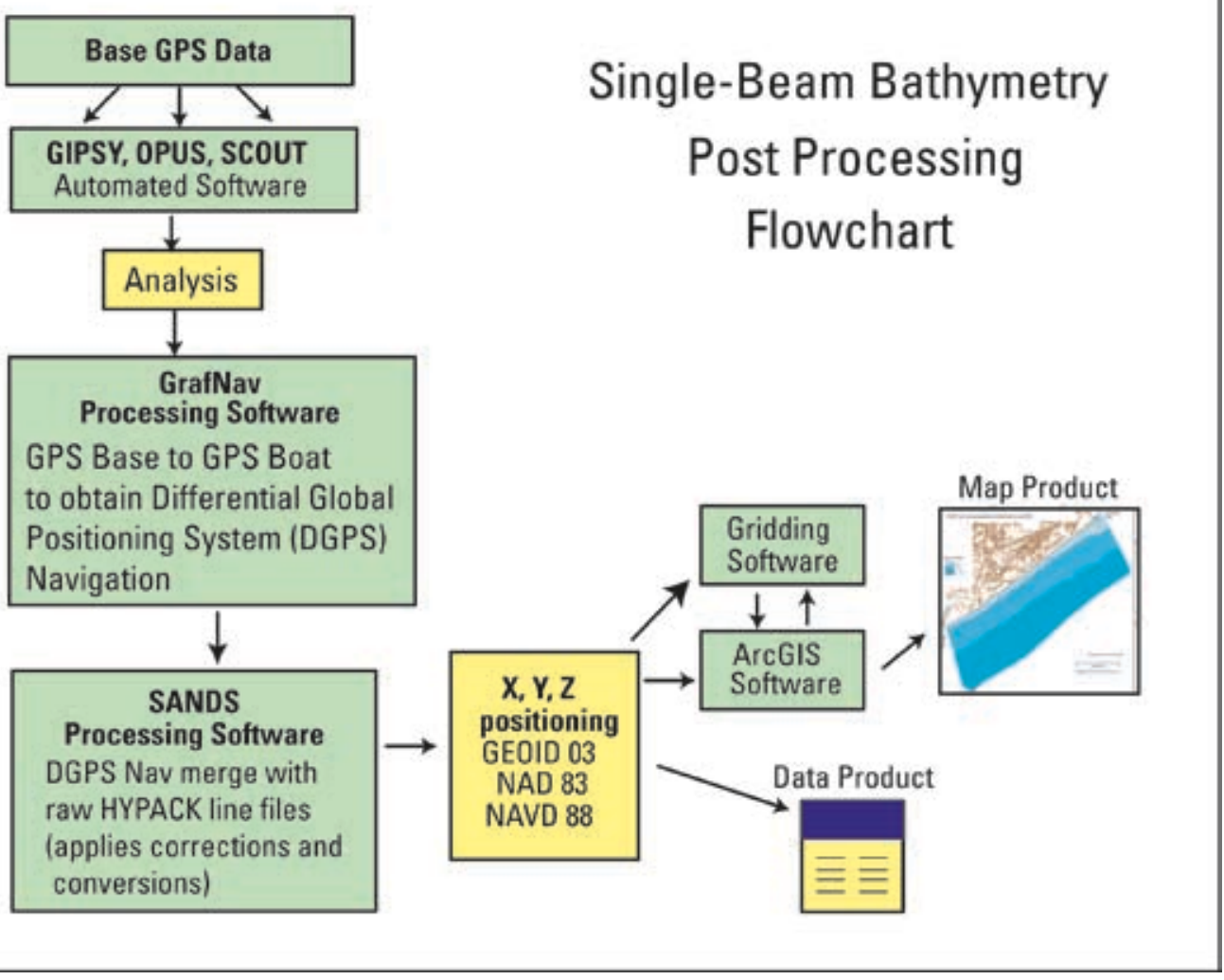

Figure 9. Diagram of the post processing workflow showing the various software components used to derive a bathymetric map and other data products. 
calculations to provide a locational accuracy of 1 to $3 \mathrm{~cm}$. The Scripps Coordinate Update Tool (SCOUT) uses the nearest three International GPS service stations (IGS) to derive a position with similar accuracy to OPUS.

Results from the three processing services are entered into a spreadsheet program for error analysis and averaging and outlying data is removed. Once each base station is averaged internally with respect to each processing service, the final position for a given base station from each service (Automated GIPSY, OPUS, SCOUT) is averaged together to get an overall final position (appendix 2).

GrafNav.-- During the survey, GPS data are recorded by the base station and the rover simultaneously. Output from GIPSY, OPUS, and SCOUT are used for kinematic processing of the rover GPS data. GrafNav software by Waypoint Consulting Incorporated processes the data from both systems to produce a single output of precise boat position and quality control information at 1$\mathrm{s}$ intervals. This provides sounding measurements that are spaced at approximately 3-m intervals along a trackline.

SANDS.-- An in-house processing program merges the data output from the GrafNav program with the bathymetric data from the HYPACK output and performs geometric corrections of the depth values caused by boat motion, time, and antenna-to-transducer offsets. The corrected depth is $(D)$ calculated as follows:
$D=1 / 2(v * t)+\mathrm{k}+d S+d R P+d G P S$

Where:

$v=$ average velocity of sound in water column

$t=$ measured elapsed time from transducer to bottom and back to transducer

$\mathrm{k}=$ system index constant (constant

fathometer bias)

$d S=$ offset from transducer face to GPS

antenna center

$d R P=$ geometric correction applied due to boat roll/pitch motion

$d G P S=$ GPS ellipsoid height relative to the GPS antenna center

Metadata.-- Federal Geographic Data

Committee (FGDC) compliant metadata are generated throughout the data collection and processing. Metadata are generated in Environmental Systems Research Institute (ESRI) ArcMap software. FGDC metadata are available in appendix 3.

\section{Soundings Grid and Contouring}

The bathymetric map generated from the soundings tracklines is shown in figure 10. A shoreline representing $0.1 \mathrm{~m}$ elevation was included in the bathymetric dataset to constrain the grid algorithm. The shoreline was digitized from a mosaic of USGS digital ortho-quarter quadrangles (DOQQ), acquired the same year as the bathymetric survey. A grid of regularly spaced depth values was generated from the processed tracklines using a convergent-grid algorithm used by Schlumberger CPS-3 software. A final grid-node spacing of $135 \mathrm{~m}$ was used. This node spacing was selected to correspond with the gridded dataset from the 1980s survey outlined in List and others (1994). Comparisons of these grids will be used for bathymetric change 


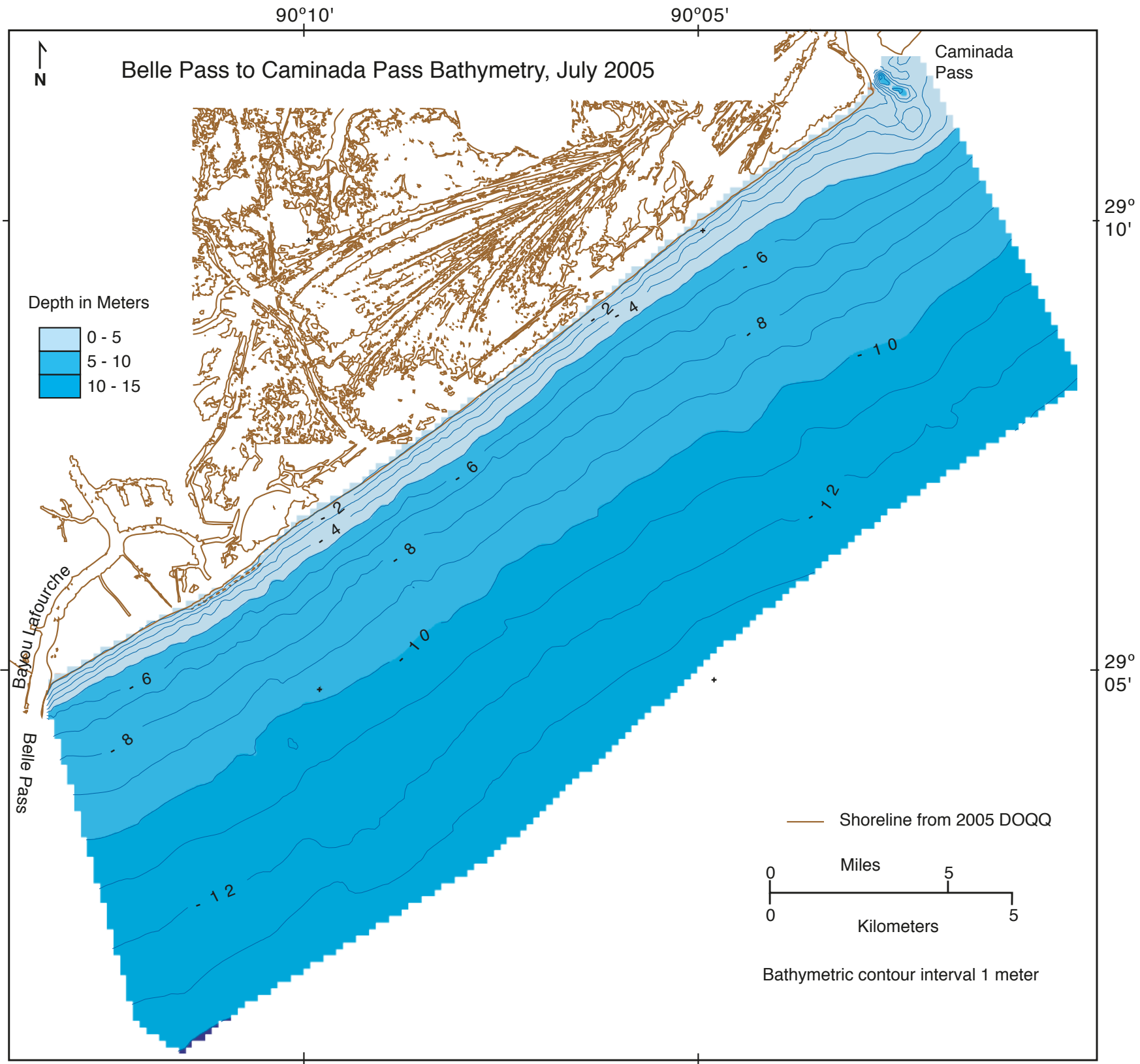

Figure 10. Bathymetric contours with color shading generated from the sounding tracklines (shown in fig. 8), Belle Pass to Caminada Pass. The contours are in reference to the NAD 83 datum. Shoreline is digitized from a 2005 digital ortho quarter quadrangle (DOOO) mosaic and was added to the dataset during the gridding process to establish gridding boundary parameters. Grid node spacing is 135 meters and contour fit is 1 meter.

analysis in a subsequent report. Depth contours were generated from the grid at a 1-m interval spacing. The contours show a relatively gentle slope (average less than $1^{\circ}$ ) from the shoreline out to $14 \mathrm{~m}$, with few deviations from this slope other than at the gulf side of the passes. Comparison of the grid to the actual sounding values shows close agreement. 


\section{Appendix 1. Processed Base Station Positions}

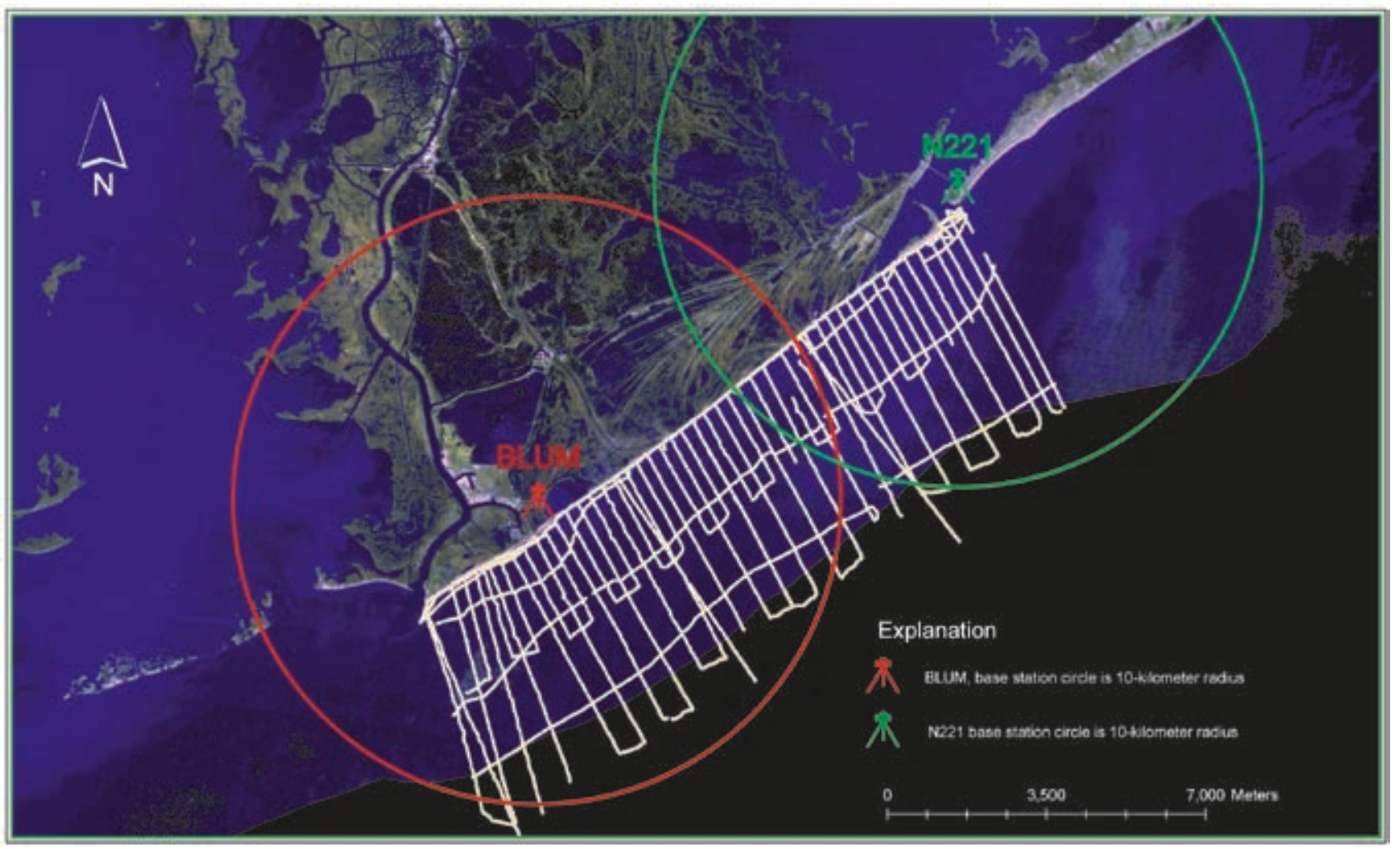

Figure A1. Map showing base station locations with a 10-kilometer radius extent for the roving boat. 

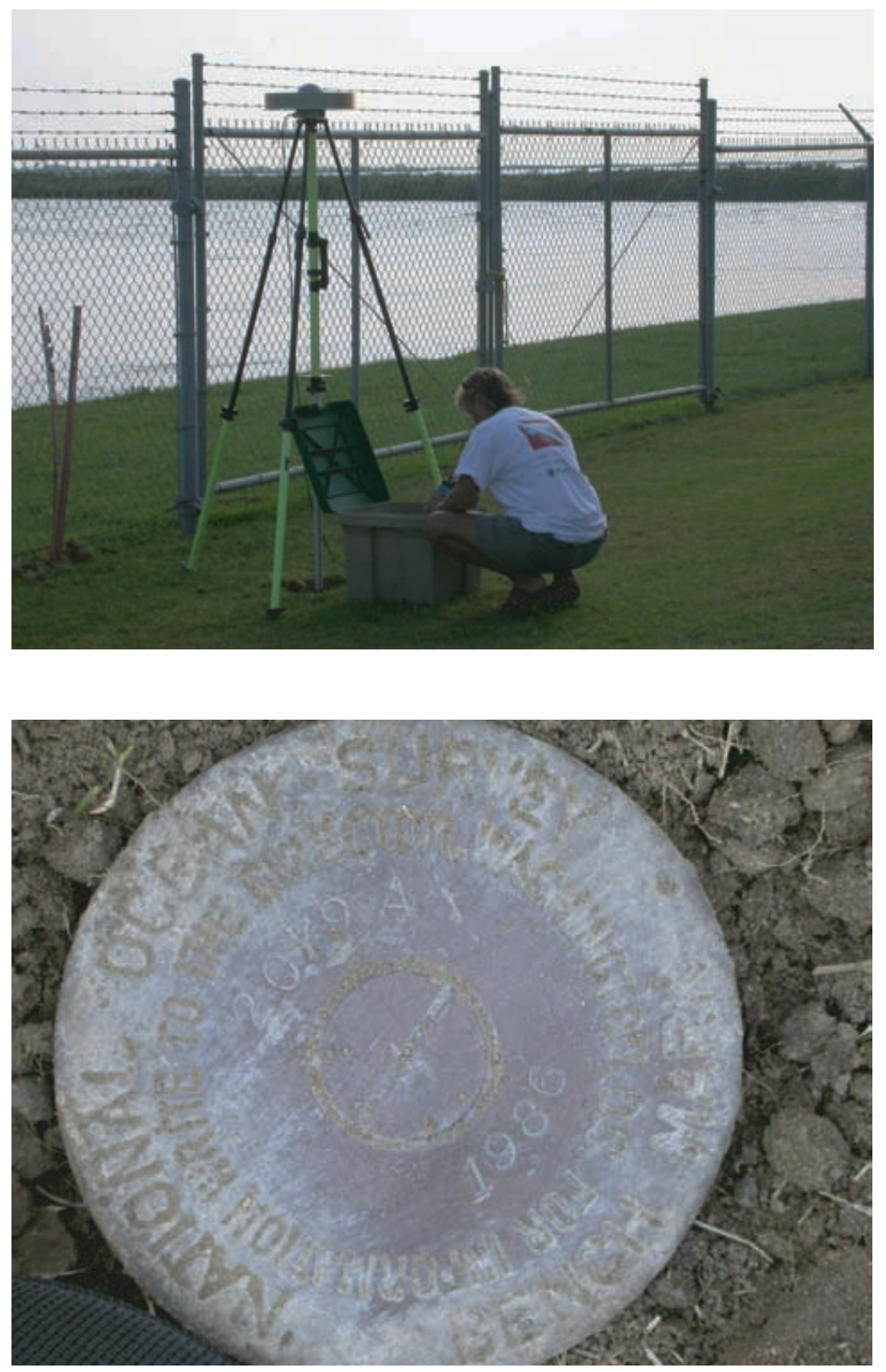

Station Name: Fourchon (LUMCON), LA

Station ID: 8762079

Stamping: National Ocean Survey 2079 A 1986

Figure A2. Photographs showing BLUM base station setup and benchmark stamping. 

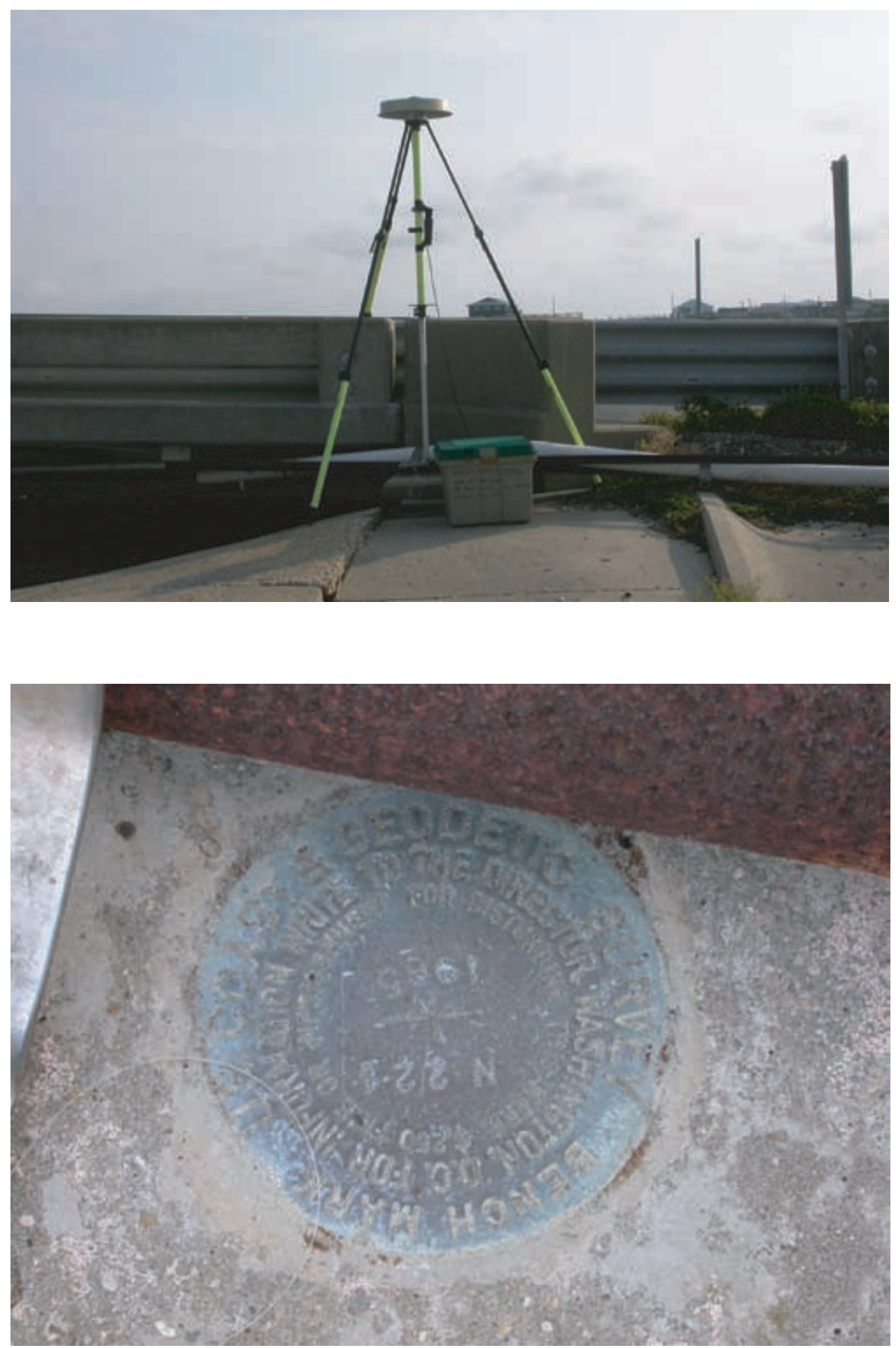

Station Name: N 221

Station PID (NGS Permanent Identifiers): AU1291

Stamping: N 2211965

Figure A3. Photographs showing N221 base station setup and benchmark stamping. 


\section{Appendix 2. Tables}

\section{Table A1. General Base Information}

[BLUM, base Lumcon, " $n$ " designates base running at night; N221, base N 221 1965; "text", designates numbers eliminated from the averages and shown here for quantitative purposes]

\begin{tabular}{|c|c|c|c|c|c|c|c|c|}
\hline \multicolumn{9}{|c|}{ General Base Information } \\
\hline Base & Date & $\begin{array}{c}\text { Julian } \\
\text { Date }\end{array}$ & Start Time & Stop Time & Start Date & Stop Date & $\begin{array}{c}\text { Total } \\
\text { Duration, } \\
\text { Seconds }\end{array}$ & $\begin{array}{c}\text { GE0ID03 } \\
\text { Height, } \\
\text { Meters }\end{array}$ \\
\hline BLUM & $7 / 27 / 05$ & 208 & 15:39:00 & 0:38:00 & 07/27/05 & 07/28/05 & 32340 & -24.024 \\
\hline BLUMn & $7 / 28 / 05$ & 208 & 0:45:00 & 14:48:00 & 07/28/05 & 07/28/05 & 50580 & -24.024 \\
\hline BLUM & $7 / 28 / 05$ & 209 & $14: 58: 00$ & $20: 28: 00$ & 07/28/05 & 07/28/05 & 19800 & -24.024 \\
\hline BLUMn & $7 / 29 / 05$ & 209 & 20:37:00 & $16: 37: 00$ & 07/28/05 & 07/29/05 & 14400 & -24.024 \\
\hline BLUM & $7 / 29 / 05$ & 210 & $16: 42: 00$ & 21:19:00 & 07/29/05 & 07/29/05 & 16620 & -24.024 \\
\hline BLUMn & $7 / 29 / 05$ & 210 & $21: 26: 00$ & $13: 41: 00$ & 07/29/05 & 07/30/05 & 27900 & -24.024 \\
\hline BLUM & $7 / 30 / 05$ & 211 & $13: 48: 00$ & 21:07:00 & 07/30/05 & 07/30/05 & 26340 & -24.024 \\
\hline BLUMn & $7 / 30 / 05$ & 211 & $21: 14: 00$ & $12: 48: 00$ & 07/30/05 & 07/31/05 & 30360 & -24.024 \\
\hline BLUM & $7 / 31 / 05$ & 212 & $12: 55: 00$ & 23:45:00 & 07/31/05 & 07/31/05 & 39000 & -24.024 \\
\hline BLUMn & $7 / 31 / 05$ & 212 & 23:52:00 & $12: 34: 00$ & 07/31/05 & 08/01/05 & 40680 & -24.024 \\
\hline BLUM & $8 / 3 / 05$ & 215 & 19:05:00 & 11:59:30 & 08/03/05 & 08/04/05 & 25530 & -24.024 \\
\hline BLUM & $8 / 5 / 05$ & 217 & 13:07:00 & 21:18:00 & 08/05/05 & 08/05/05 & 29460 & -24.024 \\
\hline BLUMn & $8 / 5 / 05$ & 217 & 21:28:00 & 11:12:00 & 08/05/05 & 08/06/05 & 36960 & -24.024 \\
\hline BLUM & 8/6/05 & 218 & 13:05:00 & 1:19:00 & 08/06/05 & 08/07/05 & 42360 & -24.024 \\
\hline & & & & & & Sum Total & 432330 & \\
\hline
\end{tabular}

\begin{tabular}{|l|l|l|l|l|l|l|l|l|}
\hline $\mathbf{N} 221$ & $8 / 1 / 05$ & 213 & $13: 10: 00$ & $1: 07: 00$ & $08 / 01 / 05$ & $08 / 02 / 05$ & 43380 & -24.111 \\
\hline $\mathbf{N 2 2 1}$ & $8 / 2 / 05$ & 214 & $17: 28: 00$ & $1: 10: 00$ & $08 / 02 / 05$ & $08 / 03 / 05$ & 58680 & -24.111 \\
\hline $\mathbf{N 2 2 1}$ & $8 / 3 / 05$ & 215 & $17: 22: 00$ & $2: 57: 00$ & $08 / 03 / 05$ & $08 / 04 / 05$ & 51900 & -24.111 \\
\hline $\mathbf{N} 221$ & $8 / 4 / 05$ & 216 & $13: 48: 00$ & $1: 13: 00$ & $08 / 04 / 05$ & $08 / 05 / 05$ & 45300 & -24.111 \\
\hline N221 & $8 / 6 / 05$ & 218 & $13: 30: 00$ & $1: 42: 00$ & $08 / 06 / 05$ & $08 / 07 / 05$ & 42480 & -24.111 \\
\hline \multicolumn{9}{|c|}{} \\
\hline
\end{tabular}


Table A2. Automated GPS Inferred Positioning System (GIPSY) Results

[BLUM, base Lumcon, " $n$ " designates base running at night; N221, base N 221 1965; JD, Julian date; NAD_83 (CORS96), North American Datum 1983 in the CORS96 reference frame; RMS, root mean square; --, designates day did not process; "text", designates numbers eliminated from the averages and shown here for quantitative purposes; criteria for eliminating outliers or erroneous values is as follows: any values with RMS errors greater than 0.040 are excluded; next the values different form the mean ellipsoid are eliminated one by one starting with the highest difference; the goal is to have all inclusive sessions be 0.050 meters or lower from the average ellipsoid height]

\begin{tabular}{|c|c|c|c|c|c|c|c|c|c|c|c|c|c|}
\hline \multicolumn{14}{|c|}{ Automated GPS Inferred Positioning System (GIPSY) Results } \\
\hline Base & JD & $\begin{array}{l}\text { NAD_83 } \\
\text { (CORS96) } \\
\text { Latitude, } \\
\text { Degrees }\end{array}$ & $\begin{array}{l}\text { NAD_83 } \\
\text { (CORS96) } \\
\text { Latitude, } \\
\text { Minutes }\end{array}$ & $\begin{array}{l}\text { NAD_83 } \\
\text { (CORS96) } \\
\text { Latitude, } \\
\text { Seconds }\end{array}$ & $\begin{array}{c}\text { NAD_83 } \\
\text { (CORS96) } \\
\text { Longitude, } \\
\text { Degrees }\end{array}$ & $\begin{array}{l}\text { NAD_83 } \\
\text { (CORS96) } \\
\text { Longitude, } \\
\text { Minutes }\end{array}$ & $\begin{array}{l}\text { NAD_83 } \\
\text { (CORS96) } \\
\text { Longitude, } \\
\text { Seconds }\end{array}$ & $\begin{array}{c}\text { NAD_83 } \\
\text { (CORS96) } \\
\text { Ellipsoid, } \\
\text { Meters }\end{array}$ & $\begin{array}{c}\text { NAD_83 } \\
\text { (CORS96) } \\
\text { Ellipsoid - } \\
\text { Antenna Height, } \\
\text { Meters }\end{array}$ & $\begin{array}{c}\text { Ellipsoid } \\
\text { Vertical RMS }\end{array}$ & $\begin{array}{c}\text { Difference } \\
\text { from Average } \\
\text { Ellipsoid, } \\
\text { Meters }\end{array}$ & $\begin{array}{c}\text { Difference } \\
\text { from Average } \\
\text { Latitude, } \\
\text { Seconds }\end{array}$ & $\begin{array}{c}\text { Difference } \\
\text { from Average } \\
\text { Longitude, } \\
\text { Seconds }\end{array}$ \\
\hline BLUM & 208 & 29 & 6 & 50.22030 & 90 & 11 & 5.01836 & -20.831 & -22.912 & 0.019 & 0.02 & 0.00037 & 0.00028 \\
\hline BLUMn & 208 & 29 & 6 & 50.22100 & 90 & 11 & 5.01886 & -20.857 & -22.938 & 0.014 & 0.01 & 0.00033 & 0.00078 \\
\hline BLUM & 209 & 29 & 6 & 50.22060 & 90 & 11 & 5.01726 & -20.806 & -22.887 & 0.036 & 0.04 & 0.00007 & 0.00082 \\
\hline BLUMn & 209 & 29 & 6 & 50.22060 & 90 & 11 & 5.01406 & -20.791 & -22.872 & 0.021 & 0.06 & 0.00007 & 0.00402 \\
\hline BLUM & 210 & 29 & 6 & 50.21960 & 90 & 11 & 5.01886 & -20.725 & -22.806 & 0.029 & 0.13 & 0.00107 & 0.00078 \\
\hline BLUMn & 210 & 29 & 6 & 50.22020 & 90 & 11 & 5.01996 & -20.901 & -22.982 & 0.036 & 0.05 & 0.00047 & 0.00188 \\
\hline BLUM & 211 & 29 & 6 & 50.22080 & 90 & 11 & 5.01856 & -20.914 & -22.995 & 0.033 & 0.06 & 0.00013 & 0.00048 \\
\hline BLUMn & 211 & 29 & 6 & 50.22030 & 90 & 11 & 5.01856 & -20.877 & -22.958 & 0.034 & 0.03 & 0.00037 & 0.00048 \\
\hline BLUM & 212 & 29 & 6 & 50.21990 & 90 & 11 & 5.01846 & -20.812 & -22.893 & 0.024 & 0.04 & 0.00077 & 0.00038 \\
\hline BLUMn & 212 & 29 & 6 & 50.22200 & $9 \theta$ & 11 & 5.01856 & -20.966 & -23.047 & 0.034 & 0.12 & 0.00133 & 0.00048 \\
\hline BLUM & 215 & 29 & 6 & 50.22050 & 90 & 11 & 5.01895 & -20.825 & -22.906 & 0.019 & 0.03 & 0.00017 & 0.00087 \\
\hline BLUM & 217 & 29 & 6 & 50.22120 & 90 & 11 & 5.01705 & -20.893 & -22.974 & 0.028 & 0.04 & 0.00053 & 0.00103 \\
\hline BLUMn & 217 & 29 & 6 & 50.22100 & 90 & 11 & 5.01655 & -20.873 & -22.954 & 0.035 & 0.02 & 0.00033 & 0.00153 \\
\hline BLUM & 218 & 29 & 6 & 50.22160 & 90 & 11 & 5.02035 & -20.827 & -22.908 & 0.025 & 0.02 & 0.00093 & 0.00227 \\
\hline \multirow{2}{*}{\multicolumn{2}{|c|}{ Average }} & 29 & 6 & 50.22067 & 90 & 11 & 5.01808 & -20.851 & -22.932 & Maximum & 0.063 & & \\
\hline & & & & & & & & & & Minimum & 0.006 & & \\
\hline
\end{tabular}

\begin{tabular}{|c|c|c|c|c|c|c|c|c|c|c|c|c|c|}
\hline N221 & 213 & 29 & 12 & 16.50769 & 90 & 2 & 24.25820 & -20.177 & -22.258 & 0.014 & 0.01 & 0.00007 & 0.00014 \\
\hline N221 & 214 & 29 & 12 & 16.50779 & 90 & 2 & 24.25859 & -20.174 & -22.255 & 0.018 & 0.02 & 0.00003 & 0.00053 \\
\hline N221 & 215 & 29 & 12 & 16.50849 & 90 & 2 & 24.25768 & -20.193 & -22.274 & 0.017 & 0.00 & 0.00072 & 0.00038 \\
\hline N221 & 216 & 29 & 12 & 16.50709 & 90 & 2 & 24.25775 & -20.214 & -22.295 & 0.016 & 0.02 & 0.00067 & 0.00031 \\
\hline N221 & 218 & 29 & 12 & 16.50761 & 90 & $z$ & 24.25870 & -20.123 & -22.204 & 0.020 & 0.07 & 0.00015 & 0.00064 \\
\hline \multirow{2}{*}{\multicolumn{2}{|c|}{ Average }} & 29 & 12 & 16.50777 & 90 & 2 & 24.25806 & -20.190 & -22.271 & Maxin & 0.024 & & \\
\hline & & & & & & & & & & Minin & 0.003 & & \\
\hline
\end{tabular}


Table A3. On Line Positioning User Service (OPUS) Results

[BLUM, base Lumcon, " $n$ " designates base running at night; N221, base N 221 1965; JD, Julian date; NAD_83 (CORS96), North American Datum 1983 in the CORS96 reference frame; RMS, root mean square; --, designates day did not process; "text", designates numbers eliminated from the averages and shown here for quantitative purposes; criteria for eliminating outliers or erroneous values is as follows: any values with RMS errors greater than 0.040 are excluded; next the values different form the mean ellipsoid are eliminated one by one starting with the highest difference; the goal is to have all inclusive sessions be 0.050 meters or lower from the average ellipsoid height]

\begin{tabular}{|c|c|c|c|c|c|c|c|c|c|c|c|c|}
\hline \multicolumn{13}{|c|}{ On Line Positioning User Service (OPUS) Results } \\
\hline Base & JD & $\begin{array}{l}\text { NAD_83 } \\
\text { (CORS96) } \\
\text { Latitude, } \\
\text { Degrees }\end{array}$ & $\begin{array}{l}\text { NAD_83 } \\
\text { (CORS96) } \\
\text { Latitude, } \\
\text { Minutes }\end{array}$ & $\begin{array}{l}\text { NAD_83 } \\
\text { (CORS96) } \\
\text { Latitude, } \\
\text { Seconds }\end{array}$ & $\begin{array}{c}\text { NAD_83 } \\
\text { (CORS96) } \\
\text { Longitude, } \\
\text { Degrees }\end{array}$ & $\begin{array}{c}\text { NAD_83 } \\
\text { (CORS96) } \\
\text { Longitude, } \\
\text { Minutes }\end{array}$ & $\begin{array}{c}\text { NAD_83 } \\
\text { (CORS96) } \\
\text { Longitude, } \\
\text { Seconds }\end{array}$ & $\begin{array}{c}\text { NAD_83 } \\
\text { (CORS96) } \\
\text { Ellipsoid, } \\
\text { Meters }\end{array}$ & $\begin{array}{c}\text { Ellipsoid } \\
\text { Vertical } \\
\text { RMS }\end{array}$ & $\begin{array}{c}\text { Difference } \\
\text { from } \\
\text { Average } \\
\text { Ellipsoid, } \\
\text { Meters } \\
\end{array}$ & $\begin{array}{c}\text { Difference } \\
\text { from } \\
\text { Average } \\
\text { Latitude, } \\
\text { Seconds } \\
\end{array}$ & $\begin{array}{l}\text { Difference } \\
\text { from Average } \\
\text { Longitude, } \\
\text { Seconds }\end{array}$ \\
\hline BLUM & 208 & 29 & 6 & 50.22040 & 90 & 11 & 5.01862 & -22.944 & 0.032 & 0.056 & 0.0000 & 0.0002 \\
\hline BLUMn & 208 & 29 & 6 & 50.22054 & 90 & 11 & 5.01847 & -22.901 & 0.051 & 0.013 & 0.0001 & 0.0000 \\
\hline BLUM & 209 & 29 & 6 & 50.22033 & 90 & 11 & 5.01883 & -22.882 & 0.052 & 0.006 & 0.0001 & 0.0004 \\
\hline BLUMn & 210 & 29 & 6 & 50.22042 & 90 & 11 & 5.01816 & -22.847 & 0.060 & 0.041 & 0.0000 & 0.0003 \\
\hline BLUMA & 211 & 29 & 6 & 50.22086 & 90 & H1 & 5.01802 & -22.910 & 0.122 & 0.022 & 0.0004 & 0.0004 \\
\hline BLUMn & 211 & 29 & 6 & 50.22064 & 90 & 11 & 5.01858 & -22.916 & 0.067 & 0.028 & 0.0002 & 0.0001 \\
\hline BLUM & 212 & 29 & 6 & 50.21995 & 90 & 11 & 5.01846 & -22.882 & 0.064 & 0.006 & 0.0005 & 0.0000 \\
\hline BLUMn & 212 & 29 & 6 & 50.22074 & 90 & 11 & 5.01858 & -22.910 & 0.073 & 0.022 & 0.0003 & 0.0001 \\
\hline BLUM & 215 & 29 & 6 & 50.22052 & 90 & 11 & 5.01850 & -22.885 & 0.059 & 0.003 & 0.0001 & 0.0000 \\
\hline BLUM & 217 & 29 & 6 & 50.22046 & 90 & 11 & 5.01850 & -22.896 & 0.043 & 0.008 & 0.0000 & 0.0000 \\
\hline
\end{tabular}

\begin{tabular}{|c|c|c|c|c|c|c|c|c|c|c|c|c|}
\hline $\mathrm{N} 2221$ & 213 & 29 & 12 & 16.50791 & $9 \theta$ & $z$ & 24.25859 & -22.249 & 0.098 & 0.019 & $0.000 z$ & $0.000 z$ \\
\hline N221 & 214 & 29 & 12 & 16.50772 & 90 & 2 & 24.25836 & -22.239 & 0.053 & 0.009 & 0.0000 & 0.0000 \\
\hline $\mathrm{N} 2221$ & 216 & 29 & 12 & 16.50777 & 90 & $z$ & 24.25829 & -22.269 & 0.074 & 0.039 & 0.0000 & 0.0001 \\
\hline Average & & 29 & 12 & 16.50767 & 90 & 2 & 24.25836 & -22.230 & Maximu & 0.009 & & \\
\hline
\end{tabular}


Table A4. Scripps Coordinate Update Tool (SCOUT) Results

[BLUM, base Lumcon; N221, base N 221 1965; " $n$ " designates base running at night; JD, Julian date; NAD_83 (CORS96), North American Datum 1983 in the CORS96 reference frame; RMS, root mean square; --, designates day did not process; --, session did not process; "text", designates numbers eliminated from the averages and shown here for quantitative purposes; criteria for eliminating outliers or erroneous values is as follows: any values with RMS errors greater than 0.040 are excluded; next the values different form the mean ellipsoid are eliminated one by one starting with the highest difference; the goal is to have all inclusive sessions be 0.050 meters or lower from the average ellipsoid height]

\begin{tabular}{|c|c|c|c|c|c|c|c|c|c|c|c|c|}
\hline \multicolumn{13}{|c|}{ Scripps Coordinate Update Tool (SCOUT) Results } \\
\hline Base & JD & $\begin{array}{l}\text { NAD_83 (CORS96) } \\
\text { Latitude, Degrees }\end{array}$ & $\begin{array}{l}\text { NAD_83 } \\
\text { (CORS96) } \\
\text { Latitude, } \\
\text { Minutes }\end{array}$ & $\begin{array}{l}\text { NAD_83 (CORS96) } \\
\text { Latitude, Seconds }\end{array}$ & $\begin{array}{l}\text { NAD_83 } \\
\text { (CORS96) } \\
\text { Longitude, } \\
\text { Degrees }\end{array}$ & $\begin{array}{l}\text { NAD_83 } \\
\text { (CORS96) } \\
\text { Longitude, } \\
\text { Minutes }\end{array}$ & $\begin{array}{l}\text { NAD_83 } \\
\text { (CORS96) } \\
\text { Longitude, } \\
\text { Seconds }\end{array}$ & $\begin{array}{l}\text { NAD_83 (CORS96) } \\
\text { Ellipsoid, Meters }\end{array}$ & $\begin{array}{c}\text { Ellipsoid } \\
\text { Vertical RMS }\end{array}$ & $\begin{array}{l}\text { Difference } \\
\text { from Average } \\
\text { Ellipsoid, } \\
\text { Meters }\end{array}$ & $\begin{array}{l}\text { Difference } \\
\text { from Average } \\
\text { Latitude, } \\
\text { Seconds }\end{array}$ & $\begin{array}{l}\text { Difference } \\
\text { from Average } \\
\text { Longitude, } \\
\text { Seconds }\end{array}$ \\
\hline BLUM & 208 & 29 & 6 & 50.22034 & 90 & 11 & 5.01850 & -22.905 & 0.019 & 0.014 & 0.00007 & 0.00013 \\
\hline BLUMn & 208 & 29 & 6 & 50.22084 & 90 & 11 & 5.01832 & -22.909 & 0.016 & 0.010 & 0.00043 & 0.00031 \\
\hline BLUM & 209 & 29 & 6 & 50.22041 & 90 & 11 & 5.01857 & -22.920 & 0.033 & 0.001 & 0.00000 & 0.00006 \\
\hline BLUMn & 209 & 29 & 6 & 50.22038 & 90 & 11 & 5.01839 & -22.927 & 0.027 & 0.008 & 0.00003 & 0.00024 \\
\hline BLUM & 210 & 29 & 6 & 50.21904 & 90 & 11 & 5.01990 & -22.858 & 0.049 & 0.061 & 0.00137 & 0.00127 \\
\hline BLUMn & 210 & 29 & 6 & 50.22016 & 90 & 11 & 5.02034 & -22.888 & 0.033 & 0.031 & 0.00025 & 0.00171 \\
\hline BLUM & 211 & 29 & 6 & 50.22070 & 90 & 11 & 5.01789 & -22.939 & 0.035 & 0.020 & 0.00029 & 0.00074 \\
\hline BLUAAF & 211 & 29 & 6 & 50.22020 & $9 \theta$ & H & 5.02214 & -22.834 & 0.042 & 0.085 & 0.00027 & 0.00357 \\
\hline BLUM & 212 & 29 & 6 & 50.22041 & 90 & 11 & 5.01843 & -22.892 & 0.021 & 0.027 & 0.00000 & 0.00020 \\
\hline BLUAAF & 212 & -- & -- & -- & -- & -- & -- & -- & -- & -- & -- & -- \\
\hline BLUM & 215 & 29 & 6 & 50.22037 & 90 & 11 & 5.01824 & -22.928 & 0.025 & 0.009 & 0.00004 & 0.00039 \\
\hline BLUM & 217 & 29 & 6 & 50.22038 & 90 & 11 & 5.01835 & -22.923 & 0.022 & 0.004 & 0.00003 & 0.00028 \\
\hline BLUMn & 217 & 29 & 6 & 50.21969 & 90 & 11 & 5.02011 & -22.930 & 0.035 & 0.011 & 0.00072 & 0.00148 \\
\hline BLUM & 218 & 29 & 6 & 50.22081 & 90 & 11 & 5.01777 & -22.945 & 0.021 & 0.026 & 0.00040 & 0.00086 \\
\hline Average & & 29 & 6 & 50.22041 & 90 & 11 & 5.01863 & -22.919 & Maximum & 0.031 & & \\
\hline
\end{tabular}

\begin{tabular}{|c|c|c|c|c|c|c|c|c|c|c|c|c|}
\hline N221 & 213 & 29 & 12 & 16.50785 & 90 & 2 & 24.25816 & -22.248 & 0.018 & 0.014 & 0.00008 & 0.00011 \\
\hline N221 & 214 & 29 & 12 & 16.50781 & 90 & 2 & 24.25809 & -22.238 & 0.022 & 0.024 & 0.00004 & 0.00004 \\
\hline $\mathrm{N} 2224$ & 215 & $z 9$ & 12 & 16.50756 & $9 \theta$ & $z$ & 24.255082 & -22.357 & 0.027 & 0.089 & $\theta .00021$ & 0.00223 \\
\hline N221 & 216 & 29 & 12 & 16.50767 & 90 & 2 & 24.25819 & -22.312 & 0.023 & 0.050 & 0.00010 & 0.00014 \\
\hline N221 & 218 & 29 & 12 & 16.50774 & 90 & 2 & 24.25776 & -22.248 & 0.019 & 0.014 & 0.00003 & 0.00029 \\
\hline \multirow{2}{*}{\multicolumn{2}{|c|}{ Average }} & 29 & 12 & 16.50777 & 90 & 2 & 24.25805 & -22.262 & Maximum & 0.050 & & \\
\hline & & & & & & & & & Minimum & 0.014 & & \\
\hline
\end{tabular}




\section{Table A5. Combined Average of GIPSY, OPUS, and SCOUT}

[GIPSY, Automated GPS Inferred Positioning System; OPUS, On Line Positioning User Service; SCOUT, Scripps Coordinate Update Tool; BLUM, base Lumcon; N221, base N 221 1965; NAD_83 (CORS96), North American Datum 1983 in the CORS96 reference frame]

\begin{tabular}{|c|c|c|c|c|c|c|c|c|c|}
\hline \multicolumn{10}{|c|}{ Combined Average of GIPSY, OPUS, and SCOUT } \\
\hline $\begin{array}{c}\text { Process } \\
\text { Type }\end{array}$ & Base & $\begin{array}{l}\text { NAD_83 } \\
\text { (CORS96) } \\
\text { Latitude, } \\
\text { Degrees }\end{array}$ & $\begin{array}{l}\text { NAD_83 } \\
\text { (CORS96) } \\
\text { Latitude, } \\
\text { Minutes }\end{array}$ & $\begin{array}{l}\text { NAD_83 } \\
\text { (CORS96) } \\
\text { Latitude, } \\
\text { Seconds }\end{array}$ & $\begin{array}{c}\text { NAD_83 } \\
\text { (CORS96) } \\
\text { Longitude, } \\
\text { Degrees }\end{array}$ & $\begin{array}{c}\text { NAD_83 } \\
\text { (CORS96) } \\
\text { Longitude, } \\
\text { Minutes }\end{array}$ & $\begin{array}{c}\text { NAD_83 } \\
\text { (CORS96) } \\
\text { Longitude, } \\
\text { Seconds }\end{array}$ & $\begin{array}{c}\text { Average } \\
\text { Ellipsoid, } \\
\text { Meters }\end{array}$ & $\begin{array}{c}\text { Difference } \\
\text { from Average } \\
\text { Ellipsoid, } \\
\text { Meters }\end{array}$ \\
\hline GIPSY & BLUM & 29 & 6 & 50.22067 & 90 & 11 & 5.01808 & -22.932 & 0.019 \\
\hline OPUS & BLUM & 29 & 6 & 50.22041 & 90 & 11 & 5.01847 & -22.888 & 0.025 \\
\hline \multirow[t]{4}{*}{ SCOUT } & BLUM & 29 & 6 & 50.22041 & 90 & 11 & 5.01863 & -22.919 & 0.006 \\
\hline & Average & & & 50.22050 & & & 5.01839 & -22.913 & \\
\hline & & & & & & & & Maximum & 0.006 \\
\hline & & & & & & & & Minimum & 0.025 \\
\hline GIPSY & N221 & 29 & 12 & 16.50777 & 90 & 2 & 24.25806 & -22.271 & 0.017 \\
\hline OPUS & N221 & 29 & 12 & 16.50767 & 90 & 2 & 24.25836 & -22.230 & 0.024 \\
\hline \multirow[t]{4}{*}{ SCOUT } & N221 & 29 & 12 & 16.50777 & 90 & 2 & 24.25805 & -22.262 & 0.007 \\
\hline & Average & & & 16.50774 & & & 24.25816 & -22.254 & \\
\hline & & & & & & & & Maximum & 0.007 \\
\hline & & & & & & & & Minimum & 0.024 \\
\hline
\end{tabular}




\section{Table A6. Final Numbers Compared to Published Numbers}

[BLUM, base Lumcon; N221, base N 221 1965; NAD_83 (CORS96), North American Datum 1983 in the CORS96 reference frame; "0" designates orthometric height; “E” designates ellipsoid height; "G" designates GEOID03 height; WGS84, World Geodetic System 1984 in the (GR1150) reference frame; NAVD88, North American Vertical Datum 1988; cm, centimeters]

\begin{tabular}{|c|c|c|c|c|c|c|c|c|c|}
\hline \multicolumn{10}{|c|}{ Final Numbers Compared to Published Numbers } \\
\hline Base & $\begin{array}{l}\text { NAD_83 } \\
\text { (CORS96) } \\
\text { Latitude, } \\
\text { Degrees }\end{array}$ & $\begin{array}{l}\text { NAD_83 } \\
\text { (CORS96) } \\
\text { Latitude, } \\
\text { Minutes }\end{array}$ & $\begin{array}{l}\text { NAD_83 } \\
\text { (CORS96) } \\
\text { Latitude, } \\
\text { Seconds }\end{array}$ & $\begin{array}{c}\text { NAD_83 } \\
\text { (CORS96) } \\
\text { Longitude, } \\
\text { Degrees }\end{array}$ & $\begin{array}{c}\text { NAD_83 } \\
\text { (CORS96) } \\
\text { Longitude, } \\
\text { Minutes }\end{array}$ & $\begin{array}{c}\text { NAD_83 } \\
\text { (CORS96) } \\
\text { Longitude, } \\
\text { Seconds }\end{array}$ & $\begin{array}{c}\text { WGS84 } \\
\text { (GR1150) } \\
\text { Ellipsoid, } \\
\text { Meters }\end{array}$ & $\begin{array}{c}0=E-G \\
\text { GE0ID03 } \\
\text { NAVD88, } \\
\text { Meters }\end{array}$ & Comments \\
\hline \multicolumn{10}{|c|}{ Final Numbers (USGS) } \\
\hline N221 & 29 & 12 & 16.50774 & 90 & 2 & 24.25816 & -22.254 & 1.857 & $+/-2.5 \mathrm{~cm}$ vertical \\
\hline \multicolumn{10}{|c|}{ Published Numbers from National Geodetic Survey (NGS) and National Ocean Service (NOS) } \\
\hline BLUM & 29 & 6 & 48.00000 & 90 & 11 & 6.00000 & -22.954 & 1.070 & NOS \\
\hline BLUM & 0 & 0 & 2.22050 & 0 & 0 & -0.98161 & 0.041 & 0.041 & \\
\hline N221 & 0 & 0 & -0.00014 & 0 & 0 & -0.00035 & -0.014 & -0.013 & $+/-2.4 \mathrm{~cm}$ vertical \\
\hline
\end{tabular}




\section{Appendix 3 - Metadata}

\section{Bathymetric Survey of the Nearshore from Belle Pass to Caminada Pass, Louisiana: Methods and Data Report}

Metadata also available as

\section{Metadata:}

- Identification_Information

- Data_Quality_Information

- Spatial_Data_Organization_Information

- Spatial_Reference_Information

- Entity_and_Attribute_Information

- Distribution_Information

- Metadata_Reference_Information

Identification_Information:

Citation:

Citation_Information:

Originator: Nancy T. DeWitt

Originator: James, G. Flocks

Originator: Mark Hansen

Originator: Mark Kulp

Originator: B.J. Reynolds

Publication_Date: 2007

Publication_Time: 2007

Title:

Bathymetric Survey of the Nearshore from Belle Pass to Caminada Pass, Louisiana: Methods and Data Report

Series_Information:

Series_Name: U. S. Geological Survey Data Series

Issue_Identification: Data Series 312, CD-ROM

Other_Citation_Details:

DeWitt, N.T., Flocks, J. G., Hansen, Mark, Kulp, Mark, Reynolds, B.J., 2007, Bathymetric Survey of the Nearshore from Belle Pass to Caminada Pass, Louisiana: Methods and Data Report: U.S. Geological Survey Data Series 312 CD-ROM. Also available online at http:// pubs.usgs.gov/

Description:

Abstract:

The U.S. Geological Survey (USGS), in cooperation with the University of New Orleans 
(UNO) and the Louisiana Department of Natural Resources (LDNR), conducted a highresolution, single-beam bathymetric survey along the southern Louisiana coastal zone from Belle Pass to Caminada Pass. The survey consisted of 483 line-kilometers of data acquired in July and August of 2005. This report outlines the methodology and provides the data from the survey. Analysis of the data and comparison to a similar bathymetric survey completed in 1989 show significant loss of seafloor and shoreline retreat, which is consistent with previously published estimates of shoreline change in the study area.

Purpose:

This project is a collection of high-resolution single-beam modern bathymetry data along the rapidly retreating Caminada-Moreau headland in the southern coastal zone, Louisiana, from Belle Pass eastward to Caminada Pass. These bathymetric data provide a 2005 dataset which succeeds a portion of the Louisiana Barrier Island Erosion Study: Atlas of Sea-Floor Changes from 1878 to 1989 by List and others (1994). The survey lines from Belle Pass to Caminada Pass (page 15 of the 1994 atlas) were digitized and resurveyed in 2005 in efforts to report sediment distribution (loss/gain) and shoreline transgression/regression along the CaminadaMoreau headland since the 1989 surveys.

Time_Period_of_Content:

Time_Period_Information:

Range_of_Dates/Times:

Beginning_Date: July 2005

Ending_Date: August 2005

Currentness_Reference: publication date

Status:

Progress: Complete

Maintenance_and_Update_Frequency: As needed

Spatial_Domain:

Bounding_Coordinates:

West_Bounding_Coordinate: 901343.81016

East_Bounding_Coordinate: 895945.54004

North_Bounding_Coordinate: 291158.53268

South_Bounding_Coordinate: 290035.41249

Data_Set_G-Polygon:

Data_Set_G-Polygon_Outer_G-Ring:

Keywords:

Theme:

Theme_Keyword: high-resolution maps

Theme_Keyword: System for Accurate Nearshore Depth Surveying

Theme_Keyword: SANDS

Theme_Keyword: Global Positioning System

Theme_Keyword: GPS

Theme_Keyword: mapping

Theme_Keyword: survey

Theme_Keyword: depth

Theme_Keyword: bathymetric

Theme_Keyword: bathymetry

Theme_Keyword: navigation

Theme_Keyword: accuracy 
Theme_Keyword: HYPACK

Theme_Keyword: GrafNav

Theme_Keyword: point data

Theme_Keyword: single beam

Theme_Keyword: hydrographic surveys

Theme_Keyword: HYPACK MAX

Theme_Keyword: Seafloor Atlas

Theme_Keyword: List and others, 1994

Theme_Keyword: Louisiana Department of Natural Resources

Theme_Keyword: LDNR

Theme_Keyword: United States Geological Survey

Theme_Keyword: USGS

Theme_Keyword: FISC - St. Petersburg, FL

Theme_Keyword: headland

Theme_Keyword: OPUS

Theme_Keyword: Gipsy

Theme_Keyword: Automated Gipsy

Theme_Keyword: SCOUT

Theme_Keyword: NAVD88

Theme_Keyword: NAD83

Theme_Keyword: UTM15

Theme_Keyword: Marimatech

Theme_Keyword: E-SEA-103

Place:

Place_Keyword: Belle Pass

Place_Keyword: Caminada Pass

Place_Keyword: Caminada-Moreau headland

Place_Keyword: nearshore

Place_Keyword: southern Louisiana coastal zone

Place_Keyword: Louisiana

Place_Keyword: Fourchon

Access_Constraints:

Any use of these data signifies a user's agreement to insure all portions of the metadata are read and clearly understood before using these data in order to protect both user and the USGS interest.

Use_Constraints:

Acknowledgment of the USGS, Florida Integrated Science Center (FISC), St. Petersburg, FL, and the University of New Orleans, Department of Earth and Environmental Sciences, New Orleans, LA, as the source for the data would be appreciated in products developed from these data and such acknowledgements as is standard for citation and legal practices for data source is expected by users of this data. Users should be aware of comparisons with other datasets for the same area from other time periods which may be inaccurate due to inconsistencies resulting from different collection procedures, mapping procedures and lab or computer analysis. Although the USGS is making these datasets available to others who may find the data of value, USGS does not warrant, endorse, or recommend the use of this data for any given reason. 
Point_of_Contact:

Contact_Information:

Contact_Person_Primary:

Contact_Person: Nancy T. DeWitt

Contact_Organization: USGS

Contact_Position: Marine Geologist

Contact_Address:

Address_Type: mailing and physical address

Address: 600 4th Street South

City: St. Petersburg

State_or_Province: FL

Postal_Code: 33701

Country: USA

Contact_Voice_Telephone: 727-803-8747 x3058

Contact_Facsimile_Telephone: 727-803-2030

Contact_Electronic_Mail_Address:ndewitt@usgs.gov

Data_Set_Credit:

We would like to thank UNO and the LDNR for their partnership on this project.

Native_Data_Set_Environment:

Microsoft Windows XP version 2002 Service Pack 2; ESRI ArcCatalog 9.1 (build 750)

\section{Data_Quality_Information:}

Attribute_Accuracy:

Attribute_Accuracy_Report:

The accuracy of the attributes (latitude, longitude, and depth) is dependent on the accuracies of the equipment used to measure their values. See horizontal and vertical positional accuracy for further information.

Logical_Consistency_Report:

A fixed 1-meter bar is used for calibrating the USGS fathometer for shallow water surveys. The 1-meter bar is sufficient, as most shallow water surveys are conducted in 3 meters of water or less, and a very accurate bar check is mandated. The USGS bar is attached to the boat directly below the transducers. The USGS bar consists of a 1.5-inch aluminum pipe connected horizontally to a flat plate which is anchored to the boat. Because of the short bar length, this check only accounts for index errors of the echo system and does not account for speed-of-sound variations with depth. In shallow water surveys the high sound velocity to depth ratio and the assumed mixing of the water tend to decrease the significance of sound velocity variations due to salinity and temperature gradients in the water column. For these reasons, using an average sound velocity of 1,500 meters per second $(\mathrm{m} / \mathrm{s})$ in combination with the daily bar check is suitable within the depth range of surveying. Full-phase-carrier GPS data are acquired simultaneously by the reference and boat receivers. Reference station GPS data are first used to derive reference station coordinates (latitude, longitude, elevation) and later used for kinematic processing of the boat GPS data. All kinematic data processing for this study were processed using GrafNav software by Waypoint, Inc. This processing step produces an accurate boat position and elevation at 1-second intervals, or about 10 feet (3 meters) apart along a track line. 


\section{Completeness_Report:}

Data are complete. Surveys are conducted only during optimal weather conditions (surveying is not performed during storms or when winds are above 15 knots). Weather conditions, such as heavy storms, lightning storms, and heavy cloud cover, and water clarity affect the collection process. Surveying was halted when GPS cycle slips occurred or when Percent Dilution of Position (PDOP) values were greater than 3.0. These weather problems result in poor or inaccurate readings from the GPS unit. Any questionable data points are removed or reprocessed through the GPS processing software.

Positional_Accuracy:

Horizontal_Positional_Accuracy:

Horizontal_Positional_Accuracy_Report:

The accuracy of the horizontal positions (latitude and longitude) is based on the accuracy of the Ashtech dual-channel (Z-Xtreme), full-carrier-phase resolving geodetic differential GPS receivers.

Quantitative_Horizontal_Positional_Accuracy_Assessment:

Horizontal_Positional_Accuracy_Value: Boat +/- 4 centimeters RMS

Horizontal_Positional_Accuracy_Explanation:

The accuracy of horizontal position is based upon a measure of the GPS quality parameters: combined horizontal and vertical differences, RMS, PDOP, and quality flag. A bias of less than 1 centimeter is introduced by inaccuracies of the reference station absolute horizontal position. The accuracy of LIDAR data is based on ranging measurements, which are based on the time interval from the transmitted pulse to a point in the returned laser backscatter or waveform.

Vertical_Positional_Accuracy:

Vertical_Positional_Accuracy_Report:

The accuracy of the vertical position is based on the accuracy of the Ashtech dual-channel (Z-Xtreme), full-carrier-phase resolving geodetic differential GPS receivers.

Quantitative_Vertical_Positional_Accuracy_Assessment:

Vertical_Positional_Accuracy_Value: Boat +/- 10 centimeters RMS

Vertical_Positional_Accuracy_Explanation:

The accuracy of single-beam data is based on the crossing readings conducted during the surveying and a measure of the GPS quality parameters: combined horizontal and vertical differences, RMS, PDOP, and quality flag. In general, 85 percent of the soundings are better than +/- 6 centimeters RMS. A bias of less than 3 centimeters is introduced by inaccuracies of the reference station absolute vertical position.

Lineage:

Process_Step:

Process_Description:

Points containing $\mathrm{x}, \mathrm{y}$, and $\mathrm{z}$ (latitude, longitude, and depth) data are collected through a USGS-developed surveying system, the System for Accurate Nearshore Depth Surveying (SANDS). The SANDS system consists of a shallow draft boat equipped with two Ashtech Z-Xtreme GPS receivers which acquire full-phase-carrier signals from the NAVSTAR GPS constellation. The USGS SANDS utilizes Ashtech Z-Xtreme dual frequency, 12-channel full-carrier-phase GPS receivers. Dorne-Margolin type choke ring antennas are used at the reference station and on the boat. GPS acquisition interval is 1 second (1 hertz). To minimize the adverse effects of vessel motion, the SANDS system is equipped with a TSSDMS-05 heave, pitch, and roll compensator. Motion acquisition interval is 0.05 seconds 
(20 hertz). The scientific grade echosounder or fathometer used in the SANDS system is a Marimatech E-SEA-103. Sounding acquisition interval is 0.1 seconds (10 hertz). The boat is navigated and all sensor data acquired using Coastal Oceanographics Inc. HYPACK surveying software. The GPS data from the reference point (base station) and the GPS data from the boat (rover) are processed together using Waypoint Consulting, Inc., GrafNav GPS processing software, which produces the differential navigation file for the survey session. The USGS SANDS software merges this differential navigation file with all senor data based upon time, performs geometric corrections, and outputs final $\mathrm{x}, \mathrm{y}, \mathrm{z}$ data relative to NAVD88 via GEOID03. The $\mathrm{x}, \mathrm{y}, \mathrm{z}$ data are then imported into CPS-3 Software by Schlumberger and gridded at 135 grid node spacing. This grid node spacing corresponds with the gridded datasets from the 1980s survey outlined in List and others (1994).

Process_Date: 2005 - 2006

Process_Contact:

Contact_Information:

Contact_Person_Primary:

Contact_Person: Nancy T. DeWitt

Contact_Organization: USGS

Contact_Position: Marine Geologist

Contact_Address:

Address_Type: mailing and physical address

Address: 600 4th Street South

City: St. Petersburg

State_or_Province: FL

Postal_Code: 33701

Country: USA

Contact_Voice_Telephone: 727-803-8747 x3058

Contact_Facsimile_Telephone:727-803-2030

Contact_Electronic_Mail_Address: ndewitt@usgs.gov

Spatial_Data_Organization_Information:

Direct_Spatial_Reference_Method: Point

Point_and_Vector_Object_Information:

Spatial_Reference_Information:

Horizontal_Coordinate_System_Definition:

Geodetic_Model:

Horizontal_Datum_Name: North American Datum of 1983

Vertical_Coordinate_System_Definition:

Altitude_System_Definition:

Depth_System_Definition:

Depth_Datum_Name: North American Vertical Datum of 1988

Depth_Resolution: 0.01

Depth_Distance_Units: meters

Depth_Encoding_Method: Implicit coordinate 


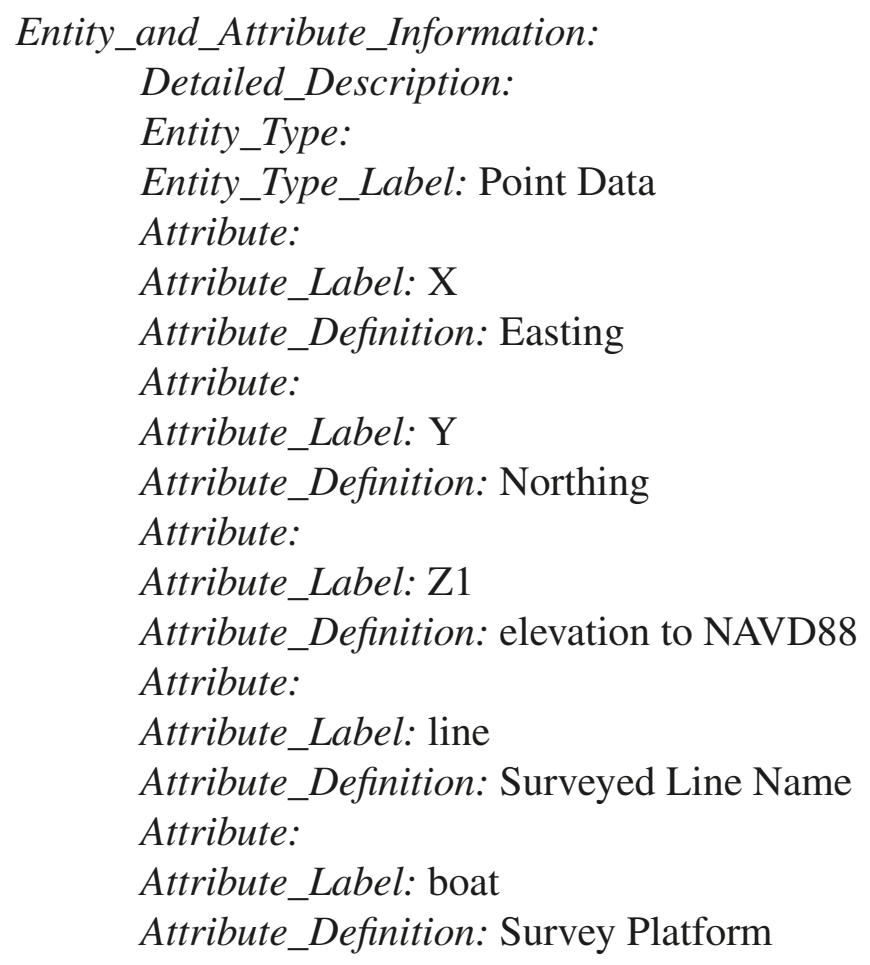

Distribution_Information:

Distributor:

Contact_Information:

Contact_Person_Primary:

Contact_Person: Nancy T. DeWitt

Contact_Organization: USGS

Contact_Position: Marine Geologist

Contact_Address:

Address_Type: mailing and physical address

Address: 600 4th Street South

City: St. Petersburg

State_or_Province: FL

Postal_Code: 33701

Country: USA

Contact_Voice_Telephone: 727-803-8747 x3058

Contact_Facsimile_Telephone: 727-803-2030

Contact_Electronic_Mail_Address: ndewitt@usgs.gov

Resource_Description: Digital Data

Distribution_Liability:

Although these data have been processed successfully on a computer system at the designated principal investigator's facility, no warranty expressed or implied is made regarding the accuracy or utility of the data on any other system or for general or scientific purposes, nor shall the act of distribution constitute any such warranty. This disclaimer applies both to individual use of the data or aggregate use with other data. It is strongly recommended that these data are directly acquired from the official USGS integrated science data server or from 
the principal investigator and not indirectly through other sources which may have changed the data in some way. It is also strongly recommended that careful attention be given to the contents of the metadata file associated with these data. The Principal investigator shall not be held liable for improper or incorrect use of the data described and (or) contained herein. So, these data are provided as is and without any expressed or implied warranties. In addition, use of trade names or commercial products in the metadata file is solely for providing specific information, and does not imply recommendation or endorsement. Any downloading and use of these data signifies a user's agreement to comprehension and compliance of the disclaimer. Insure all portions of the metadata are read and clearly understood before using the data in order to protect both user and principal investigator's interests.

Standard_Order_Process:

Fees: none

Metadata_Reference_Information:

Metadata_Date: 20061215

Metadata_Review_Date: 20070516

Metadata_Contact:

Contact_Information:

Contact_Person_Primary:

Contact_Person: Nancy T. DeWitt

Contact_Organization: USGS

Contact_Position: Marine Geologist

Contact_Address:

Address_Type: mailing and physical address

Address: 600 4th St. South

City: St. Peterbsurg

State_or_Province: FL

Postal_Code: 33701

Country: USA

Contact_Voice_Telephone: 727-803-8747 x3058

Contact_Facsimile_Telephone: 727-803-2030

Contact_Electronic_Mail_Address: ndewitt@usgs.gov

Metadata_Standard_Name: FGDC Content Standards for Digital Geospatial Metadata

Metadata_Standard_Version: FGDC-STD-001-1998

Metadata_Time_Convention: local time

Metadata_Security_Information:

Metadata_Security_Classification: Unclassified

Metadata_Extensions:

Profile_Name: ESRI Metadata Profile 